\title{
Nutritional Management of Disturbances in Lipoprotein Concentrations
}

\author{
Somayeh Hosseinpour-Niazi, Parvin Mirmiran and Fereidoun Azizi
}

Additional information is available at the end of the chapter

http://dx.doi.org/10.5772/47868

\section{Introduction}

Atherogenic dyslipidemia includes increase in blood concentrations of LDL cholesterol, total cholesterol, triglycerides and decrease in high-density lipoprotein cholesterol, both of which are frequently associated with the development of cardiovascular diseases (CVDs) $[1,2]$ .Treatment of dyslipidemia can reduce the risk of CVDs [3]. In both industrialized and nonindustrialized countries, the prevalence of dyslipidemia is increasing (4-7), therefore management of dyslipidemia has become a mainstay of routine clinical practice for both public health and clinicians. Although the benefits of lipid-lowering therapy have been demonstrated most conclusively, the role of diet determinants in dyslipidemia needs to be further considered [8]. Diet plays an important role in the concentrations of lipoprotein and is the primary intervention for patients with dyslipidemia. Understanding the relationships between dietary determinants and dyslipidemia and the effect of diet on lipoprotein concentrations may help to identify the dietary changes needed to reduce health risks [2]. Dietary changes, including reduced intakes of saturated fat and cholesterol, increased intakes of polyunsaturated fatty acids, fish, fruits and vegetables, and reduced energy intakes may have beneficial effects on lipoprotein concentrations [9-12]. One important aspect of diet is dietary patterns that address the effect of the diet as a whole and thus may provide insight beyond the effects described for single nutrients or foods [13]. The effects of some dietary patterns including the Mediterranean diet, the dietary stop to hypertension (DASH) and traditional dietary patterns, on lipoprotein particles need to be discussed [14, 15, 16]. In addition, other aspects of diet, including herbal, phytochemical, and dietary supplement (plant stanols and sterols) also play important roles in the prevention and treatment of dyslipidemia and may improve lipoprotein concentrations [17]. We searched the medical literature for studies of the effects of diet and its component including macronutrient, dietary food groups, dietary patterns and herbal on disturbances of lipoprotein concentrations. The purpose of this chapter is to update current knowledge on 
the role of the following dietary determinants in lipoprotein concentrations and dyslipidemia: including 1) macronutrients (total fat, saturated fatty acids, trans fatty acids, n-6 polyunsaturated fatty acids, n-3 polyunsaturated fatty acids, dietary cholesterol, carbohydrate and protein), 2) food groups (grains and cereal, fruit and vegetables, dairy products, nuts, beans and legumes, and meat, fish, poultry and eggs), 3) dietary patterns (Mediterranean diet, Dietary to Stop Hypertension, western diet and healthy diet), and therapeutic life style change (TLC), 4) dietary supplements, (plant stanols and sterols), herbal and phytochemicals.

\section{Diet and lipoprotein}

Lipoprotein concentrations are affected by both genetic and environmental factors. Among environmental factors such as physical activity and smoking, diet is an important component in preventing and improving dyslipidemia. Diet intervention is recommended by the National Cholesterol Education Program (NCEP) guidelines as first-line therapy for the management of disturbances in lipoprotein concentrations. Also the Third report of the NCEP recommended that if dietary therapy do not improve disturbances in lipoprotein concentrations, non-pharmacologic therapeutic factors such as viscous fiber and plant stanols and sterols should be recommended prior to advancing to drug therapy[18].

\section{Macronutrient and lipoprotein}

\subsection{Total fat}

The Nutrition Committee of the American Heart Association (AHA) emphasises on that diets providing up to $40 \%$ of dietary energy as primarily unsaturated fat (20\% MUFA, $10 \%$ SFA, $10 \%$ PUFA and $1 \%$ TFA) were as heart healthy as low-fat diets $(<30 \%$ of dietary energy) [19]. The effects of different dietary fatty acids on lipid profiles should be considered in the evaluation of strategies for controlling of disturbances in lipoprotein concentrations. Changes in dietary fat composition are clearly associated with changes in lipoprotein concentrations. Types of dietary fatty acids include saturated fatty acids (SFAs), monounsaturated fatty acid (MUFAs), polyunsaturated fatty acid (PUFAs) and dietary cholesterol, the effects of which on lipoprotein concentrations will be discussed.

\subsection{Dietary saturated fatty acids (SFAs)}

Among the dietary fatty acids only dietary SFAs and trans fatty acids increase LDL cholesterol concentrations [18]. The major sources of dietary SFAs are fast foods, processed foods, high-fat dairy products (whole milk, cheese, butter, ice cream, and cream), high-fat red meats, tropical oils such as palm oil, coconut oil, and palm kernel oil, baked products and mixed dishes containing dairy fats, shortening, and tropical oils. Dietary SFAs increase LDL and total cholesterol concentrations, in comparison with all dietary fatty acids except trans fatty acids [20-21], by inhibiting LDL receptor activity and enhancing apolipoprotein (apo) $\beta$-containing lipoprotein production [22]. Every 1 percent increase of total energy from 
dietary SFAs raises the serum LDL cholesterol about 2 percent. Conversely, a 1 percent reduction in saturated fatty acids will reduce serum cholesterol by about 2 percent [23,24]. The LDL cholesterol-raising effect of dietary SFAs depends on the intake of dietary cholesterol and PUFAs. In high intakes of dietary cholesterol, dietary SFAs decreased LDL receptor activity and increased plasma LDL concentrations [25]. However, in the adequate of dietary PUFAs (5-10\% of total energy), dietary SFAs have no effect on LDL clearance [22]. In addition different dietary SFAs have different effects on lipoprotein concentrations [29]. Short chain SFAs have been shown to have a stronger LDL cholesterol raising effect, such that lauric acid (12:0) raised LDL cholesterol the most, followed by myristic (14:0) and palmitic (16:0) acids. In contrast, stearic acid (18:0), as a long chain SFA, has no effect on LDL and HDL cholesterol or the TC: HDL cholesterol ratio, and even lowers serum cholesterol $[27,28]$. Finally, the effects of dietary SFAs can be modulated by the foods in which they are contained. Cheeses may have smaller effects on LDL cholesterol concentrations than butter, and fermented dairy foods, such as yogurt, have been associated with LDL reductions [29]. Reduced intakes of dietary SFAs and cholesterol are first steps for the purpose of achieving the LDL cholesterol goal $(<100 \mathrm{mg} / \mathrm{dl})$. To maximize LDL cholesterol lowering by reducing dietary SFAs, it will be necessary to lower intakes of dietary SFAs approximately to $<7$ percent of total energy [18]. However the replacement of dietary SFAs with other macronutrients is important. Although replacement of dietary SFAs with carbohydrate decrease total, LDL, and HDL cholesterol, it also increases triglycerides [20]; however replacement of dietary SFAs by PUFAs decreases concentrations of total, LDL, and the LDL/HDL cholesterol ratio by decreasing LDL cholesterol production and increasing LDL clearance [30]. Although replacement of dietary SFAs with PUFAs has been shown to decrease HDL cholesterol, it decreases LDL cholesterol even more substantially; thus, the HDL:LDL ratio is increased [23] and the TC:HDL cholesterol ratio is decreased [26]. Replacement of $5 \%$ of total energy from SFAs with PUFAs reduces CHD risk by $42 \%$ [31]. Replacement of dietary SFAs with MUFAs has also been associated with improving lipoprotein concentrations, although this effect is slightly less than when PUFAs are the replacement dietary fatty acid [23]. Replacement of dietary SFAs with both MUFAs and carbohydrate decrease LDL cholesterol; however replacement with MUFA was associated with lower reductions in HDL cholesterol and lower arises in triglyceride concentrations [32].

\subsection{Trans fatty acids}

Trans fatty acids contain at least one double bond in the trans configuration [40] and were the most harmful macronutrient that increase disturbances in lipoprotein concentrations $[26,33,34]$. Dietary trans fatty acids, produced during the hydrogenation of either vegetable or fish oils (industrial TFA), are found in manufacturing products such as cookies, pastries, and salad dressings; trans fatty acids are also formed during anaerobic bacterial fermentation of unsaturated fatty acids that occurs in the rumen of polygastric animals such as cattle, sheep, and goats (natural trans fatty acids), and hence found in dairy products derived from the animals' milk and meat $[33,35]$. Industrial and natural trans fatty acids contain similar types of these fatty acids, but in different proportions. Industrial trans fatty 
acids contain trans isomers of oleic acid, the major ones being C18:1 trans-9 ( elaidic acid) and C18: 1 trans-10 [35]. Consumption of industrial trans fatty acids increases total, LDL cholesterol, and total to HDL cholesterol ratio and the LDL to HDL cholesterol ratio [33, 3537] and decrease HDL cholesterol [40]. Data on the effects of natural trans fatty acids on plasma lipoproteins in humans are inconsistent. An equivalent of $1 \%$ natural trans fatty acids of daily energy, has no significant effect on total cholesterol, LDL cholesterol, apo B, triglyceride concentrations but may be associated with a reduction in plasma HDL cholesterol concentrations [38]. However high intakes of natural trans fatty acids, but not low intakes, have adverse effects [39]. Therefore both natural and industrial trans fatty acids have detrimental effects on lipoprotein concentrations and their intakes should be limited [40]. The effects of trans fatty acids on lipid profiles are also variable, depending on their chain length; long chain trans fatty acids may have more adverse effect on lipid profiles. Partially hydrogenated fish oil or trans alpha-linolenic acid had more detrimental effect on lipoprotein compared with isocaloric amount of partially hydrogenated soy bean oil $[37,41]$. Effect of trans fatty acids on lipoprotein concentrations is a current topic of debate. Trans fatty acid intake increases lipoprotein a and triglycerides when substituted for dietary SFAs [42,43]. Issues related to the potential change in lipoprotein a levels induced by trans fatty acid intake and risk for disease need to be clarified.

Dietary guidelines for American 2010 emphasize that consumption of trans fatty acids should be reduced as much as possible by limiting foods that contain sources of these fatty acids [43]. On the basis of these data, it should be attempts to substitute unhydrogenated oil for hydrogenated or SFAs in diet.

\subsection{Monounsaturated fatty acids}

Monounsaturated fatty acids have received increased attention as being potentially beneficial for their association with low rates of CHD in olive-oil consuming populations of the Mediterranean style diet [18]. The most common form of dietary MUFAs is oleic acid (18:1 n-9), which occurs in the cis form. Olive oil, canola oil, and sunflower oil are the main sources of dietary MUFAs. Oleic acid is an effective hypocholesterolemic factor when substituted for dietary SFAs. MUFA-rich oil consumption has been one of the strategies recommended for modulating the plasma lipid profile in humans. Diets containing high MUFA-rich foods reduce plasma total and LDL cholesterol levels and enrich LDL particles with cholesteryl oleate, a change in LDL particle composition that has been shown to confer atherogenicity [23, 45-48]. Also compared with diets rich in saturated fat, MUFA-rich diets lower apolipoprotein $\beta$ concentrations along with declines in LDL cholesterol level $[49,50]$. Consumption of MUFA-rich diets also induces lower triglycerides and higher HDL cholesterol concentrations compared with low-fat, high-carbohydrate diets [51]. Long term MUFA-rich diets result in an earlier postprandial peak in plasma triglyceride and apo $\beta-48$ concentrations [52,53]; this mechanism is not clear, however oleic acid has been shown to be preferentially esterified into triglycerides in the enterocyte [54], which may be result a faster entry rate of chylomicrons into the circulation, reflecting accelerated rates of digestion and 
absorption or upregulation of chylomicron synthesis and secretion [55]. However MUFArich diets increase clearance of plasma triglycerides compared with isocaloric SFA-rich or high complex carbohydrate diets and therefore decrease triglyceride concentrations [51,56,57]. MUFA substitution for dietary SFAs suggest an effective dietary strategy for improving disturbances of lipoprotein concentrations, which currently recommended in most national and international dietary guidelines [18].

\subsection{N-6 Polyunsaturated fatty acids}

Dietary n-6 PUFAs such as linoleic acid (18:2) are widely found in a variety of vegetables and vegetables oils [58]. Conjugated linoleic acid (CLA), a group of naturally occurring fatty acids that are mainly present in foods from ruminant sources, is a collective term used to describe positional and geometric derivatives of linoleic acid containing conjugated double bonds [59].

CLA have beneficial effects on lipoprotein disturbances. CLA reduced total, LDL and VLDL cholesterol, especially atherogenic apolipoprotein $\beta$-rich lipoproteins and triglycerides concentrations [60,61]. CLA increases the excretion of sterols and consequently decreases serum cholesterol concentration [86].

\subsection{N-3 Polyunsaturated fatty acids}

Dietary sources of n-3 PUFAs are limited. The shorter chain n-3 PUFAs FA, $\alpha$-linolenic acid (ALA), is found in many plants, but the longer chains eicosapentaenoic acid (EPA) and docosahexaenoic acid (DHA) are produced almost exclusively by cold water algae, which are, in turn, ingested by fish. Humans cannot synthesize the n-3 double bond, but they do have the elongase and desaturase enzymes to convert ALA to EPA and DHA, a conversion, which however is an inefficient process. The conversion of ALA to EPA may be further reduced as a result of large amounts of n- 6 FA in the diet, which compete for the same enzymes. Some studies however have found that ALA, irrespective of n-6 PUFAs, has a beneficial effect of lipid profiles [63]. Mechanism of actions of the medium- and long chain n-3 fatty acids appears to be independent. ALA exerts most of its effects by modulating lipoproteins, while EPA and DHA may reduce triglyceride synthesis [64]. Experts currently recommend the consumption of EPA and DHA, rather than ALA, to meet dietary goals for dietary n-3 PUFA [65]. Long-chain n-3 PUFA reduce triglyceride concentrations. An intake of 4 g EPA and DHA per day results in a $25-30 \%$ decrease of fasting triglyceride concentrations in both normolipidaemic and hypertriacylglycerolaemic subjects (66). Compares EPA and DHA, EPA-ethyl ester shows no change in triglyceride concentrations, suggesting that DHA is the active agent in fish oil, that decreases triglyceride concentrations. Therefore among long chain n-3 PUFAs, EPA may produce favourable effects on triglyceride and HDL cholesterol concentrations $[67,68]$. The hypotriglyceridaemic effect of long chain n-3 PUFAs, mediated by several mechanisms such as enhanced hepatic fatty acid oxidation [69], inhibition of fatty acid and triglyceride synthesis, reduced assembly and secretion of VLDL triglyceride concentrations [70], facilitates triglyceride rich lipoprotein removal through enhanced LPL 
activity in plasma [71]. Significant increases in HDL have been observed after DHA supplementation [67,68,72,73]; it may be related to decreased cholesteryl ester transfer protein activity that reduces the exchange from HDL cholesterol ester and VLDL, resulting in larger, more cholesterol-rich HDL cholesterol particles [74,75].

Inconsistent effects of DHA on total and LDL cholesterol levels have been shown; some investigators found a LDL cholesterol-raising effect $[68,76]$ or no significant changes in total cholesterol or LDL cholesterol concentration [77,78]. After supplementation with n-3 Long chain PUFA, limited amounts of triglycerides are available for packaging into VLDL, which results in VLDL particles with low triglycerides that are readily converted to LDL, increases LDL cholesterol concentrations [79]. N-3 PUFAs could increase production of LDL via conversion of VLDL to LDL by increased lipolysis of VLDL and/or increased lipolytic activity or decreased clearance of LDL, by decreases in LDL receptor binding activity or reduced LDL receptor expression [80]. ALA, an n-3 polyunsaturated fatty acid found mainly in plant sources, including flaxseed oil, canola oil, and walnuts, is a metabolic precursor of DHA and EPA and any risk reduction may be mediated through conversion to these fatty acids; ALA cannot be synthesized by humans, and therefore, it is an essential fatty acid in diet [58]. Although evidence indicates that consumption of long chain n-3 PUFAs from seafood reduces the risk factors of cardiovascular disease, the effect of ALA intake in these risk factors is less well established. Daily supplementation with ALA-rich flaxseed is reported to reduce total cholesterol, LDL-cholesterol $[81,82]$. Weight of the evidence favors recommendations for modest dietary consumption of ALA (2 to $3 \mathrm{~g}$ per day) for primary and secondary prevention of CHD [58]. The relationship between ALA intake and CHD risk was seen among participants who consumed very little seafood; among men with limited seafood intake, each $1 \mathrm{~g}$ per day ALA intake was associated with 50\% lower risk of CVDs; in contrast among subjects with some seafood intake, ALA intake was not associated with CHD risk. If benefits of ALA are greatest when EPA and DHA intakes are very low, the consumption of plant sources of n-3 fatty acids may be particularly important for CHD prevention among individuals who do not regularly consume fish [58].

\subsection{Dietary cholesterol}

The main source of dietary cholesterol is eggs, which contribute about one-third of the cholesterol in the diet; intake of dietary cholesterol has increased in recent year. Other sources of dietary cholesterol include animal products, dairy, meats, poultry, and shellfish [83]. High cholesterol intakes increase LDL cholesterol and the degree of rise varies from person to person. On average, the response of serum cholesterol to dietary cholesterol as revealed is approximately $10 \mathrm{mg} / \mathrm{dL}$ per $100 \mathrm{mg}$ dietary cholesterol per $1000 \mathrm{kcal}$ [84,85]. A recent meta-analysis showed that dietary cholesterol raises the ratio of total to HDL cholesterol, adversely affecting the serum cholesterol profile [86].

\subsection{Carbohydrate}

Recommendations to decrease fat and increase carbohydrate intake have come under scrutiny. Diets low in fat necessarily has a high proportion of carbohydrates, and high 
carbohydrate diet increase triglycerides, reduce HDL cholesterol concentrations, and increase LDL cholesterol concentrations [87]. In addition to carbohydrate intake, the type of carbohydrate, according to glycemic index, most likely influences lipid profiles [88]. Glycemic index refers to the value obtained by feeding a carbohydrate load and measuring the level of blood glucose. Using the glycemic index, carbohydrates with a low glycemic index may decrease triglyceride concentrations and increase HDL cholesterol [89]. Also substituting low-GI foods for high-GI foods lowers triglyceride concentrations by 15 to $25 \%$ [138]. High-carbohydrate diets increase triglyceride concentrations, compared to high-fat diets [91] via enhance hepatic lipogenesis [92] and decrease the synthesis of lipoprotein lipase [93]. A high carbohydrate diet also increases glucose and insulin concentrations, the latter increasing lipogenesis, leading to increases in triglyceride concentrations, triglycerideenriched VLDL particles, and increases the LDL cholesterol concentrations [94]. Therefore reductions in dietary carbohydrate have been associated with reduced concentrations of LDL cholesterol [95] and increase means LDL particle size [96].

High carbohydrate diets ( $>60$ percent of total energy) are associated with lipoprotein disturbances; reduction in the content of carbohydrate have beneficial effects on lipid profiles. However substitution of carbohydrate with other macronutrients is important. When carbohydrates are substituted for SFAs, the fall in LDL cholesterol levels equals that with monounsaturated fatty acids, and however, compared with MUFAs, this substitution frequently causes a fall in HDL cholesterol and a rise in triglycerides [23,97]. When dietary carbohydrate is consumed along with high-fiber diets, however, the rise in triglycerides or fall in HDL cholesterol has been reported to be reduced [98,99]. Addition of n-3 PUFA to low-fat, high-carbohydrate diets decreases the adverse effects of carbohydrate on blood lipids $[51,100]$. Also refined- and whole grains, as sources of carbohydrate, have an essential role in the metabolism of lipid profiles, that will be discussed in the section on food groups. In a relatively short period of time, dietary consumption of fructose has increased several fold above the amount present in natural foods, because of the use of high fructose corn sweeteners and sucrose in manufactured foods [101]. In human diets approximately onethird of dietary fructose comes from fruit, vegetables, and other natural sources and twothirds is added to beverages and food in the diet (e.g. soft drinks, fruit-flavored drinks, candies, jams, syrups, and bakery products). Although there is little evidence that modest amounts of fructose have detrimental effects on carbohydrate and lipid metabolism, larger doses have been associated with numerous metabolic abnormalities, suggesting that high fructose consumption adversely affects health. High levels of plasma triacylglycerols are a well-established consequence of dietary fructose intake [101]. Numerous mechanisms have been suggested to explain this phenomenon [102,103], e.g. enhanced hepatic lipogenesis, and therefore overproduction of VLDL $[102,104]$.

\subsection{Protein}

Plant sources of protein are predominantly legumes, dry beans, nuts, and, to a lesser extent, grain products and vegetables, which are low in saturated fats and cholesterol. Animal sources of protein include dairy products, egg whites, fish, poultry, and meats. Dietary 
protein in general has little effect on lipoprotein profiles. However, substituting plant protein including wheat gluten, soy proteins for animal protein decrease serum cholesterol [104,105]. Advice on the use of soy foods to displace animal products is consistent with the AHA advisory on soy [107], which states that $50 \mathrm{~g} / \mathrm{d}$ soy protein consumption reduces approximate 3\% LDL-C with no apparent dose-response effect [108]. Maximum reduction in LDL cholesterol was achieved when $\sim 50 \mathrm{~g}$ of soy protein when was replaced meat or dairy protein [109]. Soy is a complex protein with a globulin fraction to which its cholesterollowering effect has been attributed; this fraction digested to peptides with inhibitory effects on cholesterol synthesis [110]. Isoflavones or the saponins found in soy, are also responsible for the cholesterol-lowering effect of soy $[111,112]$. Soy and other vegetable proteins also reduce oxidized LDL due to antioxidant activity [112,113].

\section{Dietary food groups and lipoprotein}

\subsection{Grains and cereal}

Based on evidence from both population and intervention studies, the recommended intake of whole grains of the 2005 Dietary Guidelines for Americans, is at least three ounces per day [114]. The Dietary Guidelines Advisory Committee (DGAC) 2010 Report emphasizes fiber-rich carbohydrate foods such as whole grains and vegetables, fruits, and cooked dry beans and peas, it specifically recommends that half of the grains consumed be whole grains, hence some whole grains should replace refined grains [115]. Similar recommendations are made by the American Heart Association [116] and the American Diabetes Association [117]. Whole grains are referred to as "complex" or "high-quality" carbohydrates, mainly due to their dietary fiber content [118], which has a beneficial effect on body weight, and lipid profiles because they are usually less energy-dense and more satiating than refined-grain foods [119] may be due to their high fiber content. Among whole grains, oat and barley have an advantage over wheat and brown rice in lowering serum lipids [120,121,122], contain viscous fibres, including $\beta$-glucacon [118] that lower serum cholesterol; $3.5 \mathrm{~g}$ of $\beta$-glucan from oats reduces LDL-C by $5 \%[123,124]$. $\beta$-glucan interferes with reabsorption of bile acids and cholesterol by binding to bile acids, leading to increase bile acid excretion and lowering the bile acid levels in the liver and thereby increasing the conversion rate of cholesterol to bile acids. A viscous fiber intake of $10-25 \mathrm{~g} / \mathrm{d}$ is recommended by the National Cholesterol Education Program's Adult Treatment Panel III as an additional diet option to decrease LDL cholesterol; an intake of 5-10 g/d lowers LDL-C by about $5 \%$ [126].

\subsection{Fruit and vegetables}

The 2010 Dietary Guidelines for Americans, recommend consuming sufficient amounts (5-13 servings, depending on energy needs) and a varieties of fruits and vegetables to reduce the risk of developing chronic diseases [115]; fruits, vegetables, or both should be emphasized at each meal, being major sources of vitamins $\mathrm{C}$, E, and A, beta-carotene, other vitamins, fiber, flavonoids, and some minerals. Snacks and desserts that contain fruits and/or vegetables can 
be low in saturated fat, total fat, and cholesterol, and are very nutritious [18]. Fruits and vegetable intakes do not significantly change HDL cholesterol concentrations, but do decrease total and LDL cholesterol [9,127-132]. The protective effect of fruit and vegetables against CVDs is from their water-soluble and also viscous fibers (e.g. pectins) [133]. Viscous fiber increases fecal bile acid losses [134] and chenodeoxycholic acid synthesis [135].

\subsection{Dairy products}

Dairy products are important sources of protein, calcium, phosphorus, and vitamin D. The recommendation for intakes of dairy products is 2-3 serving per day; fat-free milk or 1 percent fat milk, fat-free or low-fat cheese (e.g., $\leq 3 \mathrm{~g}$ per $1 \mathrm{oz}$ serving), 1 percent fat cottage cheese or imitation cheeses made from vegetable oils, and fat-free or low-fat yogurt are good choices. Fat-free milk and other fat-free or low-fat dairy products provide as much or more calcium and protein than whole milk dairy products, with little or no saturated fat [18].

Recent studies confirm that milk products were associated with lower small dense LDL, and triglyceride concentrations, and higher HDL cholesterol [136]. In the CARDIA study, obese subjects with more frequent consumption of dairy products showed a trend towards lower risk of dyslipidaemia [137]. Minerals (calcium, magnesium), protein (casein and whey) and vitamins (riboflavin and vitamin B-12) have the hypocholesterolaemic effect of dairy product. The possible hypolipidaemic mechanism of calcium includes decreased intestinal absorption of cholesterol, bile acids, or fat [138], decreased fatty acid synthesis, increasing lipolysis, all of which lead to decreased triacylglycerol stores [139]. Milk proteins (whey) [140] or peptides [141] may also play a role. Whey may act independently or synergistically with the calcium; attenuate lipogenesis, and accelerate lipolysis [142]. Dairy products contain SFAs that could affect the blood lipid profile. A recent meta-analysis of 21 prospective cohort studies showed that the harmful effects of SFAs on CHD are still controversial [143]. An inverse association was shown between milk-specific fatty acids in serum cholesterol esters with serum cholesterol and apolipoprotein $\beta$ levels [144]. Consumption of fat-free dairy products might decrease plasma cholesterol levels, while whole milk has neither a hypo- nor hypercholesterolaemic effect [139]. SFAs in dairy products can adversely influence CHD, although the effect of SFAs on CHD risk depends on the source of calories by which it is substituted to maintain energy balance [145]. Different dairy products have different effects on the lipid profiles. The LDL-C-raising effect of cheese was less than that of butter at comparable intakes of total fat and saturated fat $[146,147]$. Butter fat may increase total and LDL cholesterol by down-regulation of LDL removal from the circulation [148]. Fermented dairy products may have a favourite effect on lipid profiles. The protective effect of yogurt [139,149], a fermented dairy product, was shown to reduce absorption of cholesterol and therefore prevent dyslipidemia; it is thought to increase calcium bioavailability through its high acidity [149]. Fermented milk products may decrease cholesterol levels more than non-fermented products [149-151]. Probiotic yogurt decreased total cholesterol by $4 \%$ and LDL cholesterol by $5 \%$ [149]. A meta-analysis of fermented dairy products has shown a possible cholesterol lowering property, through the high content of probiotic bacteria [152]. 


\subsection{Nuts}

Although nuts are high in fat, in most nuts the predominant fats are unsaturated. Studies over the last decade have demonstrated favourable effects of nuts in modifying lipid risk factors for CHD [153]. However, their use is not yet part of standard advice for patients with hyperlipidemia, despite recognized health benefits for the general population. Intake of nuts fits well with current American Heart Association guidelines [19] to replace dietary SFAs with unsaturated fats and with the National Cholesterol Education Program (NCEP) guidelines to increase intake of dietary MUFAs [153]. Less atherogenic plasma lipid profiles associated with long-term consumption of nuts [154,155]. Addition of nuts to the habitual diet of both normocholesterolemic and hypercholesterolemic subjects results in a significant reduction in plasma total and LDL cholesterol, whereas HDL remains unchanged or increases [155-158]. One-percent reductions in LDL cholesterol would be achieved with daily intakes of 4-11 $\mathrm{g}$ of walnuts, pecans, peanuts, macadamias, and pistachios [50,155,157161]. There are several components in nuts i.e. high MUFA, high PUFAs : SFAs ratio, proteins (specially high arginin), plant sterols, fiber, and associated phenolic substances, which may all contribute to the cardioprotective effect of nuts [154,162]. Also replacement of dietary SFAs with MUFAs due to the high MUFA content of nuts and high content of vitamin $\mathrm{E}$ in nuts reduce susceptibility of LDL to oxidation, a key event in the development of CVDs [233]. Consumption of almonds, either as the whole nut or the oil, lower total and LDL cholesterol concentrations. Addition of $100 \mathrm{~g}$ of almonds to the diets reduces total cholesterol by $9-16 \%$ and LDL cholesterol by $12-19 \%$ in hypercholesterolemic subjects [164]; in one study almond consumption also reduced fasting triglyceride concentrations by $14 \%$, compared with baseline [165]. Macadamia is another nut that improve lipid disturbances, and its inclusion as part of a healthy diet favourably altered the plasma lipid profile, despite the nuts being high in fat; their consumption reduced plasma total and LDL cholesterol concentrations and increase HDL cholesterol without any change in the triglyceride concentrations [166]. These changes could contribute to high MUFA intake and lower intake of PUFA and SFA consumption of macadamia nuts. Of nuts, walnuts are unique in improving dyslipidemia because they are a rich source of PUFAs, especially $\alpha$-linolenic acid and linoleic acid; $100 \mathrm{~g}$ of walnuts contain $65.2 \mathrm{~g}$ fat; mainly from PUFAs (47.2 g) including $\alpha$-linolenic acid (9.1 g) and linoleic acid (38.1 g) [167]. In a meta-analysis, consumption of walnuts resulted in decrease in total and LDL cholesterol concentrations, whereas HDL cholesterol and triglycerides were not affected [168]. Despite favourable effects of nuts on dyslipidemia, the intake of nuts should fit within the calorie and fat goal [18].

\subsection{Beans and legumes}

Legumes include a variety of beans such as navy, pinto, kidney, garbanzo, lima beans and peas such as split green peas or lentils. The Dietary Guidelines for Americans suggest consuming 3 cups of legumes per week [18, 169]. Legumes are a rich source of soluble dietary fiber and vegetable protein and have long been known to be hypercholesterolaemic foods [170,171 ]. One-half cup of cooked beans or peas can provide a range of dietary fiber from $4.6 \mathrm{~g}$ in fava beans up to $9.6 \mathrm{~g}$ fiber in navy beans, with a half cup of chick peas 
providing $6.2 \mathrm{~g}$ of total fiber, and 1.3 grams soluble dietary fiber [169]. In a meta-analysis both total and LDL cholesterol decreased, while HDL cholesterol did not change significantly, when diets uses supplemented with non-soy legumes [169]. The hypocholesterolaemic property of legumes is associated with the water-soluble fibre. Dietary fiber in legumes is not digested in the small intestine but be fermented in the colon and produces short chain fatty acids such as acetate, propionate and butyrate [172,173]; that inhibits hydroxy-3-methylglutaryl-CoA reductase, the limiting enzyme for cholesterol synthesis. Dietary fiber also decrease LDL cholesterol concentration by partially interrupting the enterohepatic circulation of bile acids via binding to bile acids in the intestines and preventing their re-absorption [174]. Consequently, an increase in the production of bile acids decreases the liver pool of cholesterol and increases uptake of serum cholesterol by the liver, decreasing thereby circulating cholesterol in the blood [175]. Another hypercholesterolemic component of legume is phytochemicals, which has been shown to reduce blood cholesterol levels and is present in small to moderate amounts in many types of legumes, such as chickpeas [176]. Dietary modification strategies that target the reduction of risk factors for CVDs should include an increase in legume consumption in addition to other strategies which have been of proven benefit [169].

\subsection{Meat, fish, poultry and eggs}

Recommendation for intakes of meat, fish and poultry are up to $5 \mathrm{oz}$ per day from lean meats (beef, pork, and lamb), poultry, and fish [18]. To achieve NCEP dietary goals, individuals are often counselled to reduce the amount and frequency of red meat consumption because of its hypercholestromia effects [177-179]. Cholesterol raising effects of red meats appears to result from high contents of SFAs $[177,179]$. Therefore, lean red meats that provide small amounts of these fatty acids do not adversely influence the blood lipid profile, compared with lean white meats. In isoenergetic low-fat diets, lean meat, fish and, poultry had similar effects on blood lipid response in both hypercholesterolemic and normocholesterolemic subjects $[178,180,181]$. Data available suggest that meat protein, per se, is not hypercholesterolemic $[177,181,182]$. The blood cholesterol-raising potential of meat products appears to be a function of their SFA fat and cholesterol contents. Therefore, substituting lean for higher fat red meat should favourably influence serum total cholesterol and LDL-C levels. Incorporating lean beef, fish, or poultry into the AHA diet can be beneficial in lower disturbances of lipid profile in patients with hypercholesterolemia $[178,183]$. Therefore the hypercholesterolemic subjects known to be at high risk for CVDs, could be advised to include lean fish as well as lean beef or poultry without skin in an AHA diet to reduce their lipoprotein disturbances [184,185]; normolipidemic subjects can also incorporate lean fish in an AHA diet [184], althought it is not necessary to eliminate or drastically reduce intake of lean red meat consumption because it is a rich source of iron, zinc and vitamin B12. One of the dietary recommendations in the prevention of CVDs is to limit egg consumption, because they have been shown to be a major source of dietary cholesterol (One egg contains $200 \mathrm{mg} / \mathrm{cholesterol}$ ) that increases both serum total and LDLcholesterol concentrations $[21,86,186]$. Several epidemiologic studies however found no 
relation between egg consumption and risk of coronary heart disease [187,188], may be because dietary cholesterol increases not only concentrations of total and LDL cholesterol but also concentrations of HDL cholesterol [21,186,189,190]. Egg intake has been also shown to promote the formation of large LDL particles, which is less atherogenic [191]. Therefore dietary recommendations aimed at restricting egg consumption should not be generalized to include all individuals [191].

\subsection{Dietary pattern}

Using single nutrients or dietary food groups have some limitations in assessing their effect on lipid profiles separately because nutrients and foods are consumed in combination. To date, dietary patterns consider how foods are consumed in combination, and are used to evaluate the effects of overall nutritional habits on health status. There are two dietary patterns that demonstrate the beneficial effect on disturbances of lipoprotein concentrations; there include the dietary to stop hypertension (DASH) and the Mediterranean diet. The DASH dietary pattern, rich in fruits, vegetables, and low-fat dairy foods, emphasizes fish, poultry, and whole grains, and is reduced in total fat, SFAs and cholesterol, red meat, sweets, and sweetened beverages [192,193]; it lowers total, LDL and HDL cholesterols, without any adverse effects on triglyceride concentrations [194]; all of these coupled with decrease in blood pressure, reduce 10-year coronary heart disease risk of approximately $12 \%$ [194]. The Mediterranean dietary pattern consists of: (a) daily consumption: of non refined cereals and products (whole grain bread, pasta, brown rice, etc), vegetables ( $2-3$ servings/ day), fruits (6 servings/day), olive oil (as the main added lipid) and dairy products (1 - 2 servings/day), (b) weekly consumption: of fish (4-5 servings/week), poultry (3 - 4 servings/week), olives, pulses, and nuts (3 servings/ week), potatoes, eggs and sweets (3-4 servings/week) and monthly consumption: of red meat and meat products $(4-5$ servings/month). It is also characterized by moderate consumption of wine $(1-2$ wineglasses/day). Mediterranean diet is a diet poor in SFAs and PUFAs but rich in MUFA (oleic acid) provided by the olive oil. The ratio of MUFAs : SFAs fat ratio is high > 2 [195]. This diet pattern is associated with reduction in total and LDL-cholesterol, and also a significant effect on triglycerides and VLDL concentrations, and a small positive or no effect on HDL-cholesterol [196-199] and improves dyslipidemia in dislipidemic patients [200]. This diet also includes antioxidant vitamins and phenolic compounds, and therefore reduces levels of circulating oxidized LDL and increases total antioxidant capacity [201]. Beside these two dietary patterns, other dietary pattern such as the western, and healthy dietary patterns affect lipoprotein profiles. The western pattern is characterized by high consumption of food such as refined grains, french fries, and red meats that have detrimental effects on lipid profiles. The healthy pattern included non-hydrogenated fat, vegetables, eggs, and fish and was negatively associated with lipoprotein disturbances [202-205]. In addition of dietary patterns, therapeutic lifestyle change is another dietary approach that ATP III recommends to reduce risks for $\mathrm{CHD}$. This dietary approach includes the following: 1) Reduced intakes of dietary SFAs ( $<7 \%$ of total calories) and cholesterol $(<200 \mathrm{mg} / \mathrm{d}), 2)$ weight reduction, 3 ) increased physical activity, and 4) therapeutic options for enhancing LDL lowering such as plant stanols/ sterols ( $2 \mathrm{~g} / \mathrm{d}$ ) and increased viscous (soluble) fiber (10-25 g/d) [18]. 


\section{Dietary supplement}

\subsection{Plant stanols and sterols}

Dyslipidemia may be treated with dietary interventions, including the daily consumption of foods with added plant stanols or plant sterols. Plant sterols are isolated from soybean and tall pine-tree oils. Also some foods such as macadamia nuts are a rich source $(1.28 \mathrm{mg} / \mathrm{g}$ lipid) of plant sterols. Plant sterols can be esterified to unsaturated fatty acids, creating sterol esters, to increase lipid solubility. Hydrogenating of sterols produces plant stanols. Plant stanols and sterols are available in commercial margarines. Daily consumption of $2 \mathrm{~g}$ plant stanols or plant sterols, expressed as free plant stanol or plant sterol equivalents improves dyslipidemia [18]. FDA confirms a daily dose of plant sterols and stanols of $2 \mathrm{~g}$ per day as safe, a dose which reduces LDL cholesterol by $10 \%$ [206], with little or no change in HDL cholesterol or triglyceride levels. There were no apparent added benefits at higher doses of palnts stanols and sterols. Plant stanols and sterols compete with absorption of dietary cholesterol and bile acid [8]. The consumption of plant stanols and sterols is an effective LDL cholesterol lowering strategy for patients who are undergoing statin therapy. The lipidlowering response to combined plant stanols and sterols/statin therapy target both intestinal and hepatic cholesterol metabolism. Consumption of plant stanols and sterols reduces intestinal cholesterol absorption and reduces hepatic cholesterol synthesis. Consumption of statins simultaneously with plant stanols and sterols inhibit hepatic cholesterol synthesis and therefore reduce in LDL cholesterol concentrations [8]. Plant sterols/stanols reduce absorption of dietary carotenoids, and decrease levels of plasma betacarotene; therefore increased intakes of fruits and vegetables are recommended with consumption of plant stanols/sterols[18].

\subsection{Herbal}

There is a need to identify additional non-pharmacologic therapeutic options for cholesterol lowering. There is also a need to find products that are more practical for the consumer than viscous fiber and plant stanols and sterols to permit widespread adoption.

\subsubsection{Flavonoid}

Flavonoids have 2 aromatic rings that are bound by an oxygenated heterocyclic ring. On the basis of their chemical structure, they are divided into several subclasses: flavones, flavonols, flavanones, flavan-3-ols, anthocyanins and isoflavones. Flavones and flavonols are found in leaf vegetables and onion. Flavanones are mainly found in grapefruits and citrus fruits. Tea and cocoa are the richest sources of flavan-3-ols. Soy and soy products such as tofu, and miso are the main sources of isoflavones [207,208]. Although increased resistance of LDL to oxidation was observed after treatment with various synthetic pharmaceutical agents, an effort is made to identify natural food products which can offer antioxidant defense against LDL oxidation. Polyphenolic flavonoids are powerful antioxidants and their antioxidative capacity is related to their chemical structure [209]. 
Incubation of LDL with flavonoids protects the lipoprotein against oxidation [210]. Certain flavonoids such as querectin could have a potentially protective role in suppression of LDL oxidation, regardless of the effect of antioxidant vitamins [211] via scavenging radicals and reduce total and LDL cholesterol concentrations, by reducing the hepatic lipogenesis [212].

\subsubsection{Tea}

The effect of tea on lipid profiles is uncertain. Although some studies have found no lipidlowering effects from green or black tea consumption, most showed hypolipidemic effects for tea [213-218]. The association between tea drinking and lipid profile concentrations was linear for up to 10 cups per day, beyond which the association disappeared [219]. Daily consumption of 10 cups of green tea was associated with a reduction of approximately $2 \%$ in serum total cholesterol [219]. Tea also is a major source of flavonoids, the predominant ones in green tea being catechins. Theaflavins are polyphenol pigments present in black tea, formed from the polymerization of catechins during fermentation of green tea [220]. Catechins reduce intestinal cholesterol absorption [221], reduce hepatic cholesterol content [222] and increase fecal excretion of total fatty acids, neutral sterols, and acidic sterols [223] and up-regulate the LDL receptor in liver cells [224]. Polyphenol in black tea also increases fecal excretion of total lipids and cholesterol [225].

\subsubsection{Chocolate}

The beneficial effects of chocolate on healthy humans have been widely addressed in recent years. Supplementation of cocoa products affects lipid profiles in subjects with cardiovascular-related diseases such as hypercholesterolemia, glucose intolerance, and hypertension as well as healthy individuals [226-228]. Consumption of cocoa and dark chocolate increase the concentration of HDL cholesterol [229] and plasma antioxidant capacity, decrease the formation of lipid oxidation products, and inhibit the oxidation of LDL [230]. In a meta-analysis study, cocoa was associated with small decreases in total and LDL cholesterol, but not HDL cholesterol concentrations [231]. Cocoa products contain more polyphenols than teas. A particular group of flavonoids, namely, the flavan-3-ols was found in chocolate (flavanols) [232]. Moderate consumption of cocoa or dark chocolate, have potential health benefits [231], however, a high dose of polyphenols has been shown to exert cytotoxic effects on liver cells [233] and higher polyphenol supplementation may counteract its beneficial biological effects on lipid metabolism [234].

\subsubsection{Fenugreek}

Fenugreek (Trigonella foenum-graecum), an annual medicinal plant of the Fabaceae family is well documented for its pharmacological properties. Fenugreek seeds have been historically used for the treatment of various chronic diseases such as diabetes, dyslipidemia, and obesity [235,236 ]. The seeds of Fenugreek contain many nutrients including protein, carbohydrates, fat, vitamin, and minerals, fiber, saponins, choline and 
trigonelline, polyphenolic flavonoids, steroid saponins, polysaccharides mainly galactomannans and 4-hydroxyisoleucine [237,239], the fiber and saponin components of the seeds have been shown to have hypocholesterolemic effect [240], and the beneficial effect of raw fenugreek seeds on elevated serum cholesterol levels has been well established [241]. Raw fenugreek seeds reduce serum total cholesterol, LDL cholesterol, VLDL cholesterol and triglyceride concentrations, without altering the HDL fraction [242]; intakes of 20-25 g in three divided doses yielded maximum benefit in the control of cholesterol concentrations [243]. Its use as a dietary adjunct however is limited because of its bitterness. Soaking and washing of fenugreek seeds in water overnight removes the bitterness to a certain extent and makes then edible $[243,244]$.

\subsubsection{Ginseng}

The beneficial metabolic effects of ginseng on lipid profiles as a hypolipidemic agent were reported over 20 years ago [245-247]. Ginseng leads to reduction of cholesterol and triglyceride concentrations in liver and serum. Administration of red ginseng powder and extract reduces plasma total cholesterol, triglycerides, FFA, and increased HDL-C [248,249 ]. Ginseng saponins may decrease blood cholesterol concentrations by increasing cholesterol excretion through bile acid formation [249,250]. Ginsenoside, one of active components of ginseng saponins, may accelerate serum cholesterol turnover by increased cholesterol degradation and excretion in the feaces notwithstanding increased hepatic cholesterogenesis [250,251]. Ginseng saponins as ginsenosides increase LDL receptors by promoting the synthesis of LDL receptors[252].

\subsubsection{Ginger}

Ginger has been listed in the "Generally Recognized as Safe" by FDA [338]; fresh ginger rhizome contains polyphenolic compounds such as gingerols; zingerone, which is the major active component and gingerol, is one of the most abundant constituents in the gingerol series and also responsible for its characteristic pungent taste [253,254]. Ginger oleo-resin and dried ginger rhizome reduce hypercholesterolaemia. The speculated mechanism for these compounds is by disrupting cholesterol absorption from the gastro-intestinal tract [255], which may be due to the presence of niacin in ginger, and it causes increased clearance of VLDL, lowers triglyceride levels, increases hepatic uptake of LDL and inhibition of cholesterogenesis [256]. Ginger powder significantly reduces the extent of lipid peroxidation and improves plasma antioxidant capacity, which decreases plasma-free radicals [257]. Moreover, polyphenolic flavonoids present in ginger may prevent coronary artery disease by reducing plasma cholesterol levels or by inhibiting LDL oxidation [258]. Reduction in serum triglycerides is dose dependent; doses of 200 and $400 \mathrm{mg} / \mathrm{kg}$ of ginger are more effective as antihypercholesterolaemics than atorvastatin when given for 4 weeks and are equivalent to it when given for shorter period under the same conditions of diet and life style for the treatment of the same pathologic condition. The triglyceride lowering effect of ginger may be due to ginger's ability to enhance lipase activity [255]. 


\subsubsection{Licorice}

Licorice root, derived from the plant Glycyrrhiza glabra is used widely in Asia as a sweetener or a spice, contains flavonoids from the flavan and chalcone subclasses, and has a antioxidative properties [259]. Licorice-derived glabridin binds to the LDL particle and protects it from oxidation by its capacity to scavenge free radicals and its property to reduce the LDL aggregation [260,261].

\section{Conclusion}

Diet therapy is the initial recommended intervention for prevention of and managing disturbances of lipoprotein concentrations, prior to advancing to drug therapy. Further research on the association between dietary components and lipoprotein disturbances is recommended.

\section{Author details}

Parvin Mirmiran*

Department of Clinical Nutrition and Dietetics, Faculty of Nutrition Sciences and Food Technology, National Nutrition and Food Technology Research Institute,

Shahid Beheshti University of Medical Sciences, Tehran, Iran

Somayeh Hosseinpour-Niazi

Nutrition Related Non-Communicable Disease, Research Institute for Endocrine Sciences,

Shahid Beheshti University of Medical Sciences, Tehran, Iran

Fereidoun Azizi

Endocrine Research Center, Research Institute for Endocrine Sciences,

Shahid Beheshti University of Medical Sciences, Tehran, Iran

\section{Acknowledgement}

The authors would like to acknowledge Ms N. Shiva for language editing of the manuscript and to express their appreciation to Emad Yuzbashian for his valuable help. This study was funded by a grant from the Research Institute of Endocrine Sciences, Shadid Beheshti University of Medical Sciences, Tehran, Iran. None of the authors had any personal or financial conflicts of interest.

\section{References}

[1] Robins SJ, Lyass A, Zachariah JP, Massaro JM, Vasan RS (2011) Insulin resistance and the relationship of a dyslipidemia to coronary heart disease: the Framingham Heart Study. Arterioscler Thromb Vasc Biol. 31: 1208-1214.

${ }^{*}$ Corresponding Author 
[2] Musunuru K (2010) Atherogenic dyslipidemia: cardiovascular risk and dietary intervention. Lipids. 45:907-914.

[3] Goff DC Jr, Bertoni AG, Kramer H, Bonds D, Blumenthal RS, Tsai MY, eat al (2006) Dyslipidemia prevalence, treatment, and control in the Multi-Ethnic Study of Atherosclerosis (MESA): gender, ethnicity, and coronary artery calcium. Circulation. 113:647-656.

[4] Hosseini-Esfahani F, Mousavi Nasl Khameneh A, Mirmiran P, Ghanbarian A, Azizi F (2011) Trends in risk factors for cardiovascular disease among Iranian adolescents: the tehran lipid and glucose study, 1999-2008. J Epidemiol. 21:319-328.

[5] Esteghamati A, Meysamie A, Khalilzadeh O, Rashidi A, Haghazali M, Asgari F, et al (2009) Third national Surveillance of Risk Factors of Non-Communicable Diseases (SuRFNCD-2007) in Iran: methods and results on prevalence of diabetes, hypertension, obesity, central obesity, and dyslipidemia. BMC Public Health.9:167.

[6] Goodman SG, Langer A, Bastien NR, McPherson R, Francis GA, Genest JJ Jr, et all (2010) DYSIS Canadian Investigators. Prevalence of dyslipidemia in statin-treated patients in Canada: results of the DYSlipidemia International Study (DYSIS). Can J Cardiol. 26:e330-335.

[7] Aguilar-Salinas CA, Gómez-Pérez FJ, Rull J, Villalpando S, Barquera S, Rojas R (2010) Prevalence of dyslipidemias in the Mexican National Health and Nutrition Survey 2006. Salud Publica Mex. 52:44-53.

[8] Rideout TC, Harding SV, Marinangeli CP, Jones PJ (2010) Combination drug-diet therapies for dyslipidemia. Transl Res. 155:220-227.

[9] Mirmiran P, Noori N, Zavareh MB, Azizi F (2009) Fruit and vegetable consumption and risk factors for cardiovascular disease. Metabolism. 58:460-8.

[10] Mirmiran P, Ramezankhani A, Azizi F (2009) Combined effects of saturated fat and cholesterol intakes on serum lipids: Tehran Lipid and Glucose Study. Nutrition. 25:526531

[11] Mirmiran P, Mirbolooki M, Heydarian P, Salehi P, Azizi F (2008) Intrafamilial associations of lipid profiles and the role of nutrition: the Tehran lipid and glucose study. Ann Nutr Metab. 52: 68-73.

[12] Azadbakht L, Mirmiran P, Hedayati M, Esmaillzadeh A, Shiva N, Azizi F(2007) Particle size of LDL is affected by the National Cholesterol Education Program (NCEP) step II diet in dyslipidaemic adolescents. Br J Nutr. 98: 134-139.

[13] Hu FB (2002) Dietary pattern analysis: a new direction in nutritional epidemiology. Curr Opin Lipidol. 13:3-9.

[14] Azadbakht L, Mirmiran P, Esmaillzadeh A, Azizi T, Azizi F (2005) Beneficial effects of a Dietary Approaches to Stop Hypertension eating plan on features of the metabolic syndrome. Diabetes Care. 28: 2823-31.

[15] Azadbakht L, Mirmiran P, Esmaillzadeh A, Azizi F (2006) Dietary diversity score and cardiovascular risk factors in Tehranian adults. Public Health Nutr. 9: 728-736.

[16] Hosseini-Esfahani F, Jessri M, Mirmiran P, Bastan S, Azizi F (2010) Adherence to dietary recommendations and risk of metabolic syndrome: Tehran Lipid and Glucose Study. Metabolism. 59: 1833-1842. 
[17] Bahadoran Z, Mirmiran P, Hosseinpanah F, Hedayati M, Hosseinpour-Niazi S, Azizi F (2011) Broccoli sprouts reduce oxidative stress in type 2 diabetes: a randomized doubleblind clinical trial. ur J Clin Nutr. 65: 972-977.

[18] National Cholesterol Education Program (NCEP) Expert Panel on Detection, Evaluation, and Treatment of High Blood Cholesterol in Adults (Adult Treatment Panel III) (2002) Third Report of the National Cholesterol Education Program (NCEP) Expert Panel on Detection, Evaluation, and Treatment of High Blood Cholesterol in Adults (Adult Treatment Panel III) final report. Circulation.106: 3143-3421.

[19] Krauss RM, Eckel RH, Howard B, et al. (2000) AHA Dietary Guidelines: revision 2000: A statement for healthcare professionals from the Nutrition Committee of the American Heart Association. Circulation 102, 2284-2299.

[20] Siri-Tarino PW, Sun Q, Hu FB, Krauss RM (2010) Saturated fat, carbohydrate, and cardiovascular disease. Am J Clin Nutr. 91:502-9.

[21] Clarke R, Frost C, Collins R, Appleby P, Peto R (1997) Dietary lipids and blood cholesterol: quantitative meta-analysis of metabolic ward studies. BMJ. 314:112-117.

[22] Dietschy JM (1998) Dietary fatty acids and the regulation of plasma low density lipoprotein cholesterol concentrations. J Nutr. 128: 444-448.

[23] Mensink RP, Katan MB (1992) Effect of dietary fatty acids on serum lipids and lipoproteins. A meta-analysis of 27 trials. Arterioscler Thromb. 12:911-919.

[24] Kris-Etherton PM, Yu S (1997) Individual fatty acid effects on plasma lipids and lipoproteins: human studies. Am J Clin Nutr;65: 1628-1644.

[25] Hayes KC, Khosla P, Hajri T, Pronczuk A (1997) Saturated fatty acids and LDL receptor modulation in humans and monkeys. Prostaglandins Leukot Essent Fatty Acids. 57: 411-418.

[26] Mensink RP, Zock PL, Kester AD, Katan MB (2003) Effects of dietary fatty acids and carbohydrates on the ratio of serum total to HDL cholesterol and on serum lipids and apolipoproteins: a metaanalysis of 60 controlled trials. Am J Clin Nutr. 77:1146-1155.

[27] Bonanome A \& Grundy SM (1988) Effect of dietary stearic acid on plasma cholesterol and lipoprotein levels. N Engl J Med. 318, 1244-1248.

[28] Grande F, Anderson JT \& Keys A (1970) Comparison of effects of palmitic and stearic acids in the diet on serum cholesterol in man. Am J Clin Nutr. 23, 1184-1193.

[29] German JB, Gibson RA, Krauss RM, et al (2009) A reappraisal of the impact of dairy foods and milk fat on cardiovascular disease risk. Eur J Nutr, 48:191-203.

[30] National Cholesterol Education Program (1994) Second report of the expert panel on detection, evaluation, and treatment of high blood cholesterol in adults (Adult Treatment Panel II). Circulation. 89:1333-445.

[31] Siri-Tarino PW, Sun Q, Hu FB, Krauss RM (2010) Saturated fatty acids and risk of coronary heart disease: modulation by replacement nutrients. Curr Atheroscler Rep. 12: 384-390.

[32] Berglund L, Lefevre M, Ginsberg HN, et al (2007) Comparison of monounsaturated fat with carbohydrates as a replacement for saturated fat in subjects with a high metabolic risk profile: studies in the fasting and postprandial states. Am J Clin Nutr. 86:1611-1620 
[33] Lichtenstein AH (1997) Trans fatty acids, plasma lipid levels, and risk of developing cardiovascular disease. A statement for healthcare professionals from the American Heart Association. Circulation. 95: 2588-2590.

[34] Sun Q, Ma J, Campos H, et al (2007) A prospective study of trans fatty acids in erythrocytes and risk of coronary heart disease. Circulation. 115: 1858-1865

[35] Brouwer IA, Wanders AJ, Katan MB (2010) Effect of animal and industrial trans fatty acids on HDL and LDL cholesterol levels in humans--a quantitative review. PLoS One. 5: 9434.

[36] Almendingen K, Jordal O, Kierulf P, Sandstad B, Pedersen JI (1995) Effects of partially hydrogenated fish oil, partially hydrogenated soybean oil, and butter on serum lipoproteins and Lp[a] in men. J Lipid Res. 36: 1370-1384.

[37] Vermunt SH, Beaufrere B, Riemersma RA, Sebedio JL, Chardigny JM, et al (2001) Dietary trans alpha-linolenic acid from deodorised rapeseed oil and plasma lipids and lipoproteins in healthy men: the TransLinE Study. Br J Nutr. 85: 387-392.

[38] Lacroix E, Charest A, Cyr A, Baril-Gravel L, Lebeuf Y, Paquin P, et al (2012) Randomized controlled study of the effect of a butter naturally enriched in trans fatty acids on blood lipids in healthy women. Am J Clin Nutr. 95: 318-25.

[39] Motard-Belanger A, Charest A, Grenier G, Paquin P, Chouinard Y, et al (2008) Study of the effect of trans fatty acids from ruminants on blood lipids and other risk factors for cardiovascular disease. Am J Clin Nutr. 87: 593-599.

[40] Mozaffarian D, Katan MB, Ascherio A, Stampfer MJ, Willett WC (2006) Trans fatty acids and cardiovascular disease. N Engl J Med. 354: 1601-1613.

[41] Almendingen K, Jordal O, Kierulf P, Sandstad B, Pedersen JI (1995) Effects of partially hydrogenated fish oil, partially hydrogenated soybean oil, and butter on serum lipoproteins and Lp[a] in men. J Lipid Res. 36: 1370-1384.

[42] Zock PL, Mensink RP (1996) Dietary trans-fatty acids and serum lipoproteins in humans. Curr Opin Lipidol. 7: 34-37

[43] United States Department of Agriculture, United States Department of Health and Human Services: Report of the Dietary Guidelines Advisory Committee on the Dietary Guidelines for Americans. Washington, DC: Government Printing Office; 2010

[44] Heyden, S (1994) Polyunsaturated and monounsaturated fatty acids in the diet to prevent coronary heart disease via cholesterol reduction. Ann. Nutr. Metab. 38: 117-122.

[45] Gustafsson I-B, Vessby B, Ohrvall M, Nydahl M (1994) A diet rich in monounsaturated rapeseed oil reduces the lipoprotein cholesterol concentration and increases the relative content of n23 fatty acids in serum in hyperlipemic subjects. Am J Clin Nutr. 59:667-74

[46] Mensink RP (1994) Dietary monounsaturated fatty acids and serum lipoprotein levels in healthy subjects. Atherosclerosis. 110. 65-68.

[47] Roche, H. M., Zampelas, A. \& Knapper, J.M.E (1998) Effect of longterm olive oil dietary intervention on postprandial triacylglycerol and factor VII metabolism. Am. J. Clin. Nutr. 68: 552-560.

[48] Ginsberg, H. N., Barr, S. L., Gilbert, A., Karmally,W., Deckelbaum, R., Kaplan, K., Ramakrishnan, R., Holleran, S. \& Dell, R. B. (1990) Reduction of plasma cholesterol 
levels in normal men on an American Heart Association Step 1 diet or a Step 1 diet with added monounsaturated fat. N. Engl. J. Med. 322: 574-579.

[49] Allman-Farinelli MA, Gomes K, Favaloro EJ, Petocz P (2005) A diet rich in high-oleicacid sunflower oil favorably alters low-density lipoprotein cholesterol, triglycerides, and factor VII coagulant activity. J Am Diet Assoc. 105: 1071-1079.

[50] Rajaram S, Burke K, Connell B, Myint T, Sabate J (2001) A monounsaturated fatty-acid pecan-enriched diet favourably alters the serum lipid profile of healthy men and women. J Nutr. 131:2275-2279.

[51] Jiménez-Gómez Y, Marín C, Peérez-Martínez P, Hartwich J, Malczewska-Malec M, Golabek I, et al (2010) A low-fat, high-complex carbohydrate diet supplemented with long-chain (n-3) fatty acids alters the postprandial lipoprotein profile in patients with metabolic syndrome. J Nutr. 140: 1595-1601.

[52] Roche HM, Zampelas A, Knapper JM,Webb D, Brooks C, Jackson KG, et al (1998) Effect of long-term olive oil dietary intervention on postprandial triacylglycerol and factor VII metabolism. Am J Clin Nutr. 68: 552-560.

[53] Roche, H. M., Zampelas, A., Jackson, K. G., Williams, C. M., Gibney, M. J. (1998) The effect of test meal monounsaturated fatty acid:saturated fatty acid ratio on postprandial lipid metabolism. Br. J. Nutr. 79: 419-424.

[54] Dashti N, Smith EA, Alaupovic P (1990) Increased production of apolipoprotein B and its lipoproteins by oleic acid in Caco-2 cells. J Lipid Res. 31:113-23.

[55] Silva KD, Kelly CN, Jones AE, Smith RD, Wootton SA, Miller GJ, et al (2003). Chylomicron particle size and number, factor VII activation and dietary monounsaturated fatty acids. Atherosclerosis. 166: 73-84.

[56] Rajaram S, Burke K, Connell B, et al (2001) A monounsaturated fatty acid-rich pecanenriched diet favorably alters the serum lipid profile of healthy men and women. J Nutr. 131:2275-2279

[57] Curb DJ, Wergowske G, Dobbs JC, Abbot RD, Huang B (2000) Serum lipid effects of a high-monounsaturated fat diet based on macadamia nuts. Arch Int Med. 160: 1154-1158.

[58] Mozaffarian D (2005)Does alpha-linolenic acid intake reduce the risk of coronary heart disease? A review of the evidence. Altern Ther Health Med. 11: 24-30.

[59] Wandders AJ, Brouwer IA, Siebelink E, Katan MB (2010) Effect of a high intake of conjugated linoleic acid on lipoprotein levels in healthy human subjects. PLoS One. 5: 9000.

[60] Kostogrys RB, Pisulewski PM (2010) Effect of conjugated linoleic acid (CLA) on lipid profile and liver histology in laboratory rats fed high-fructose diet. Environ Toxicol Pharmacol. 30: 245-250.

[61] Nicolosi RJ, Rogers EJ, Kritchevsky D, Scimeca JA, Huth PJ (1997) Dietary conjugated linoleic acid reduces plasma lipoproteins and early aortic atherosclerosis in hypercholesterolemic hamsters. Artery. 22: 26.

[62] Yang L, Yeung SY, Huang Y, Wang HQ, Chen ZY. referential incorporation of trans, trans-conjugated linoleic acid isomers into the liver of suckling rats. Br J Nutr. 2002 Mar;87(3):253-60. 
[63] Mirmiran P, Hosseinpour-Niazi S, Naderi Z, Bahadoran Z, Sadeghi M, Azizi F (2012) Association between interaction and ratio of $\omega-3$ and $\omega-6$ polyunsaturated fatty acid and the metabolic syndrome in adults. Nutrition. 27.

[64] Poudyal H, Panchal SK, Diwan V, Brown L (2011) Omega-3 fatty acids and metabolic syndrome: effects and emerging mechanisms of action. Prog Lipid Res. 50: 372-387.

[65] Kris-Etherton PM, Grieger JA, Etherton TD (2009) Dietary reference intakes for DHA and EPA. Prostaglandins Leukot Essent Fatty Acids. 81:99-104.

[66] Harris WS, Miller M, Tighe AP, Davidson MH, Schaefer EJ (2008) Omega-3 fatty acids and coronary heart disease risk: clinical and mechanistic perspectives. Atherosclerosis. 197:12-24.

[67] Egert S, Kannenberg F, Somoza V, Erbersdobler H,Wahrburg U (2009) Dietary alphalinolenic acid, EPA, and DHA have differential effects on LDL fatty acid composition but similar effects on serum lipid profiles in normolipidemic humans. J Nutr. 139:861-8

[68] Geppert J, Kraft V, Demmelmair H, Koletzko B (2006) Microalgal docosahexaenoic acid decreases plasma triacylglycerol in normolipidaemic vegetarians: a randomized trial. $\mathrm{Br}$ J Nutr. 95: 779-86.

[69] Clarke SD, Jump D (1997) Polyunsaturated fatty acids regulate lipogenic and peroxisomal gene expression by independent mechanisms. Prostaglandins Leukot Essent Fatty Acids. 57:65-9.

[70] Nestel PJ (2000) Fish oil and cardiovascular disease: lipids and arterial function. Am J Clin Nutr. 71, 228-231.

[71] Harris WS, Lu G, Rambjor GS,Walen AI, Ontko JA, Cheng Q, Windsor SL (1997) Influence of n-3 fatty acid supplementation on the endogenous activities of plasma lipases. Am J Clin Nutr. 66:254-260.

[72] Maki KC, McKenney JM, Reeves MS, Lubin BC, Dicklin MR (2008) Effects of adding prescription omega-3 acid ethyl esters to simvastatin (20 mg/day) on lipids and lipoprotein particles in men and women with mixed dyslipidemia. Am J Cardiol.102:429-33.

[73] Neff LM, Culiner J, Cunningham-Rundles S, Seidman C, Meehan D, Maturi J, Wittkowski KM, et al (2011) Algal docosahexaenoic acid affects plasma lipoprotein particle size distribution in overweight and obese adults. J Nutr. 141: 207-213.

[74] Abbey M, Clifton P, Kestin M, Belling B \& Nestel P (1990) Effect of fish oil on lipoproteins, lecithin:cholesterol acyltransferase, and lipid transfer protein activity in humans. Arteriosclerosis. 10: 85-94.

[75] Buckley R, Shewring B, Turner R, Yaqoob P, Minihane AM (2004) Circulating triacylglycerol and apoE levels in response to EPA and docosahexaenoic acid supplementation in adult human subjects. Br J Nutr. 92: 477-483.

[76] Theobald HE, Chowienczyk PJ,Whittall R, Humphries SE, Sanders TA (2004) LDL cholesterol-raising effect of low-dose docosahexaenoic acid in middle-aged men and women. Am J Clin Nutr. 79: 558-563.

[77] Conquer JA, Holub BJ (1998) Effect of supplementation with different doses of DHA on the levels of circulating DHA as non-esterified fatty acid in subjects of Asian Indian background. J Lipid Res. 39: 286-292. 
[78] Nestel P, Shige H, Pomeroy M, Cehun M, Abbey M, Raederstorff D (2002) The n-3 fatty acids eicosapentaenoic acid and docosahexaenoic acid increase systemic arterial compliance in humans. Am J Clin Nutr 76: 326-330

[79] Griffin BA (2001) The effect of n-3 fatty acids on low density lipoprotein subfractions. Lipids. 36, 91-97.

[80] Lu G, Windsor SL, Harris WS (1999) Omega-3 fatty acids alter lipoprotein subfraction distributions and the in vitro conversion of very low density lipoproteins to low density lipoproteins. J Nutr Biochem. 10:151-158.

[81] Cunnane SC, Hamadeh MJ, Liede AC, Thompson LU, Wolever TM, Jenkins DJ (1995) Nutritional attributes of traditional flaxseed in healthy young adults. Am J Clin Nutr. 61:62-8.

[82] Lucas EA, Wild RD, Hammond LJ, Khalil DA, Juma S, Daggy BP, et al (2002) Flaxseed improves lipid profile without altering biomarkers of bone metabolism in postmenopausal women. J Clin Endocrinol Metab. 87:1527-1532.

[83] Putnam J, Gerrior S (1999) Trends in the U.S. food supply, 1970-97. In: America's eating habits: changes and consequences. Washington, D.C.: United States Department of Agriculture, Economic Research Service. 133-60.

[84] Grundy SM, Barrett-Connor E, Rudel LL, Miettinen T, Spector AA (1988) Workshop on the impact of dietary cholesterol on plasma lipoproteins and atherogenesis. Arteriosclerosis. 8:95-101

[85] National Research Council. Diet and health: implications for reducing chronic disease risk. Washington, D.C.: National Academy Press, 1989: 171-201

[86] Weggemans RM, Zock PL, Katan MB (2001) Dietary cholesterol from eggs increases the ratio of total cholesterol to high-density lipoprotein cholesterol in humans: a metaanalysis. Am J Clin Nutr. 73: 885-91.

[87] Schaefer EJ, Gleason Jam (2009) Dietary fructose and glucose differentially affect lipid and glucose homeostasis J Nutr, 139:1257S-1262S

[88] Barclay AW, Petocz P, McMillan-Price J, et al (2008) Glycemic index, glycemic load, and chronic disease risk - a meta-analysis of observational studies. Am J Clin Nutr. 87:627-637.

[89] Barclay AW, Petocz P, McMillan-Price J, et al (2008) Glycemic index, glycemic load, and chronic disease risk-a meta-analysis of observational studies. Am J Clin Nutr. 87:62737.

[90] Pelkman CL (2001) Effects of the glycemic index of foods on serum concentrations of high-density lipoprotein cholesterol and triglycerides. Curr Atheroscler Rep. 3:456-461.

[91] Sacks FM, Katan M (2002) Randomized clinical trials on the effects of dietary fat and carbohydrate on plasma lipoproteins and cardiovascular disease. Am J Med.;113 Suppl $9: 13-24$.

[92] Aarsland A, Chinkes D, Wolfe RR (1997) Hepatic and whole-body fat synthesis in humans during carbohydrate overfeeding. Am J Clin Nutr. 65:1774-82

[93] McNeel RL, Mersmann HJ (2005) Low- and high-carbohydrate diets: body composition differences in rats. Obes Res. 13:1651-60. 
[94] Volek JS, Phinney SD, Forsythe CE, Quann EE, Wood RJ, Puglisi MJ, et al (2009) Carbohydrate restriction has a more favorable impact on the metabolic syndrome than a low fat diet. Lipids. 44: 297-309.

[95] Krauss RM, Blanche PJ, Rawlings RS, et al (2006) Separate effects of reduced carbohydrate intake and weight loss on atherogenic dyslipidemia. Am J Clin Nutr. 83:1025-1031

[96] Sharman MJ, Kraemer WJ, Love DM, Avery NG, Gomez AL, Scheett TP, Volek JS (2002) A ketogenic diet favorably affects serum biomarkers for cardiovascular disease in normal-weight men. J Nutr. 132: 1879-1885.

[97] Turley ML, Skeaff CM, Mann JI, Cox B (1998) The effect of a low-fat, high-carbohydrate diet on serum high density lipoprotein cholesterol and triglyceride. Eur J Clin Nutr. 52:728-32.

[98] Vuksan V, Sievenpiper JL, Owen R, Swilley JA, Spadafora P, Jenkins DJA (2000) Beneficial effects of viscous dietary fiber from Konjac-mannan in subjects with the insulin resistance syndrome: results of a controlled metabolic trial. Diabetes Care.23:9-14.

[99] Grundy SM, Florentin L, Nix D, et al. (1988) Comparison of monounsaturated fatty acids and carbohydrates for reducing raised levels of plasma cholesterol in man. Am J Clin Nutr 47: 965-969.

[100] Jiménez-Gómez Y, Marín C, Peérez-Martínez P, Hartwich J, Malczewska-Malec M (2010) A low-fat, high-complex carbohydrate diet supplemented with long-chain (n-3) fatty acids alters the postprandial lipoprotein profile in patients with metabolic syndrome. J Nutr. 140: 1595-1601.

[101] Basciano H, Federico L, Adeli K (2005) Fructose, insulin resistance, and metabolic dyslipidemia. Nutr Metab (Lond). 2: 5.

[102] Busserolles J, Zimowska W, Rock E, Rayssiguier Y, Mazur A (2002) ts fed a high sucrose diet have altered heart antioxidant enzyme activity and gene expression Life Sci. 71: 1303-1312.

[103] Girard A, Madani S, Boukortt F, Cherkaoui-Malki M, Belleville J, Prost J (2006) Fructose-enriched diet modifies antioxidant status and lipid metabolism in spontaneously hypertensive rats. Nutrition. 22: 758-766.

[104] Elliott SS, Keim NL, Stern JS, Teff K, Havel PJ (2002) Fructose, weight gain, and the insulin resistance syndrome. Am J Clin Nutr.76: 911-922.

[105] Rukmini C, Raghurm TC (1991) Nutritional and biochemical aspects of the hypolipidemic action of rice bran oil: a review. J Am Coll Nutr. 10: 593-601.

[106] Turnbull WH, Leeds AR, Edwards DG (1992) Mycoprotein reduces blood lipids in free-living subjects. Am J Clin Nutr. 55: 415-419.

[107] Erdman JW Jr (2000) AHA Science Advisory: soy protein and cardiovascular disease: a statement for healthcare professionals from the Nutrition Committee of the AHA. Circulation. 102: 2555-2559.

[108] Sacks FM, Lichtenstein A, Van Horn L, Harris W, Kris-Etherton P, Winston M (2006) Soy protein, isoflavones, and cardiovascular health: an American Heart Association Science Advisory for professionals from the Nutrition Committee. Circulation. 113: 1034-1044. 
[109] Jenkins DJ, Mirrahimi A, Srichaikul K, Berryman CE, Wang L, Carleton A, et al (2010) Soy protein reduces serum cholesterol by both intrinsic and food displacement mechanisms. J Nutr. 140: 2302-2311.

[110] Lovati MR, Manzoni C, Gianazza E, Arnoldi A, Kurowska E, Carroll KK, Sirtori CR (2000) Soy protein peptides regulate cholesterol homeostasis in Hep G2 cells. J Nutr. 130: 2543-2549.

[111] Zhuo XG, Melby MK, Watanabe S (2004) Soy isoflavone intake lowers serum LDL cholesterol: a meta-analysis of 8 randomized controlled trials in humans. J Nutr. 134: 2395-2400.

[112] Wiseman H, O'Reilly JD, Adlercreutz H, Mallet AI, Bowey EA, Rowland IR, et al (2000) Isoflavone phytoestrogens consumed in soy decrease $\mathrm{F}(2)$-isoprostane concentrations and increase resistance of low-density lipoprotein to oxidation in humans. Am J Clin Nutr. 72: 395-400

[113] Jenkins DJ, Kendall CW, Vidgen E, Augustin LS, van Erk M, Geelen A, et al (2001) High-protein diets in hyperlipidemia: effect of wheat gluten on serum lipids, uric acid, and renal function. Am J Clin Nutr. 74:57-63.

[114] United States Department of Agriculture, United States Department of Health and Human Services: Dietary Guidelines for Americans, 6th edn. Washington, DC: Government Printing Office; 2005.

[115] United States Department of Agriculture, United States Department of Health and Human Services: Report of the Dietary Guidelines Advisory Committee on the Dietary Guidelines for Americans. Washington, DC: Government Printing Office; 2010

[116] Lichtenstein AH, Appel LJ, Brands M, Carnethon M, Daniels S, Franch HA, et al (2006) Summary of American Heart Association Diet and Lifestyle Recommendations revision 2006. Arterioscler Thromb Vasc Biol. 26:2186-2191

[117] American Diabetes Association (2007) Nutrition recommendations and interventions for diabetes: a position statement of the American Diabetes Association. Diabetes Care 30: 48-65.

[118] Harris KA, Kris-Etherton PM (2010) Effects of whole grains on coronary heart disease risk. Curr Atheroscler Rep. 12: 368-376.

[119] Koh-Banerjee P, Rimm EB (2003) Whole grain consumption and weight gain: a review of the epidemiological evidence, potential mechanisms and opportunities for future research. Proc Nutr Soc. 62: 25-29

[120] Kashtan H, Stern HS, Jenkins DJ, Jenkins AL, Hay K, Marcon N, et al (1992) Wheatbran and oat-bran supplements' effects on blood lipids and lipoproteins. Am J Clin Nutr.55: 976-980.

[121] Shimizu C, Kihara M, Aoe S, Araki S, Ito K, Hayashi K, et al (2008) Effect of high betaglucan barley on serum cholesterol concentrations and visceral fat area in Japanese men - a randomized, double-blinded, placebo-controlled trial. Plant Foods Hum Nutr. 63: $21-25$

[122] Kelly SA, Summerbell CD, Brynes A, Whittaker V, Frost G (2007) Wholegrain cereals for coronary heart disease. Cochrane Database Syst Rev, 2:CD005051. 
[123] US FDA. Food labeling: health claims: soluble fiber from whole oats and risk of coronary heart disease. Docket 95P-0197. Washington, DC: US FDA; 2001. p. 15343-4.

[124] Brown L, Rosner B, Willett WW, Sacks FM (1999) Cholesterol-lowering effects of dietary fiber: a meta-analysis. Am J Clin Nutr. 69:30-42.

[125] Papathanasopoulos A, Camilleri M (2010) Dietary fiber supplements: effects in obesity and metabolic syndrome and relationship to gastrointestinal functions. Gastroenterology. 138:65-72.

[126] National Heart Lung and Blood Institute: Third Report of the Expert Panel on Detection, Evaluation, and Treatment of High Blood Cholesterol in Adults (Adult Treatment Panel III). Edited by National Cholesterol Education Program. Bethesda, MD: National Institutes of Health; 2002.

[127] Dragsted LO, Krath B, Ravn-Haren G, Vogel UB, Vinggaard AM, Bo Jensen P, et al (2006) Biological effects of fruit and vegetables. Proc Nutr Soc. ;65: 61-7.

[128] Jenkins DJ, Kendall CW, Popovich DG, Vidgen E, Mehling CC, Vuksan V, et al (2001) Effect of a very-high-fiber vegetable, fruit, and nut diet on serum lipids and colonic function. Metabolism. 50:494-503

[129] Djousse L, Arnett DK, Coon H, Province MA, Moore LL, Ellison RC (2004) Fruit and vegetable consumption and LDL cholesterol: the national heart, lung, and blood institute family heart study. Am J Clin Nutr.79: 213-217

[130] Ballesteros MN, Cabrera RM, Saucedo MS, Yepiz-Plascencia GM, Ortega MI, Valencia ME (2001) Dietary fiber and lifestyle influence serum lipids in free living adult men. J Am Coll Nutr. 20:649-655.

[131] Stone NJ (2001) Lowering low-density cholesterol with diet: the important role of functional foods as adjuncts. Coron Artery Dis. 12:547-552.

[132] Fornes NS, Martins IS, Hernan M, Velasquez-Melendez G, Ascherio A (2000) Frequency of food consumption and lipoprotein serum levels in the population of an urban area, Brazil. Rev Saude Publica. 34: 380-387

[133] Pereira MA, O’Reilly E, Augustsson K, Fraser GE, Goldbourt U, Heitmann BL, Hallmans G, et al (2004) Dietary fiber and risk of coronary heart disease: a pooled analysis of cohort studies. Arch Intern Med. 164: 370-376.

[134] Kritchevsky D, Story JA (1974) Binding of bile salts in vitro by nonnutritive fiber. J Nutr. 104:458-462.

[135] Everson GT, Daggy BP, McKinley C, Story JA (1992) Effects of psyllium hydrophilic mucilloid on LDL-cholesterol and bile acid synthesis in hypercholesterolemic men. J Lipid Res. 33:1183-1192.

[136] Sjogren P, Rosell M, Skoglund-Andersson C, Zdravkovic S, Vessby B, de Faire U, et al (2004) Milkderived fatty acids are associated with a more favorable LDL particle size distribution in healthy men. J Nutr. 134: 1729- 1735

[137] Pereira MA, Jacobs DR Jr, Van Horn L, Slattery ML, Kartashov AI, Ludwig DS (2002) Dairy consumption, obesity, and the insulin resistance syndrome in young adults: the CARDIA Study. JAMA. 287: 2081-2089. 
[138] Shahkhalili Y, Murset C, Meirim I, Duruz E, Guinchard S, Cavadini C, et al (2001) Calcium supplementation of chocolate: effect on cocoa butter digestibility and blood lipids in humans. Am J Clin Nutr. 73: 246-252.

[139] Pfeuffer M, Schrezenmeir J (2007) Milk and the metabolic syndrome. Obes Rev.8:109 118.

[140] Takeuchi T, Shimizu H, Ando K, Harada E (2004) Bovine lactoferrin reduces plasma triacylglycerol and NEFA accompanied by decreased hepatic cholesterol and triacylglycerol contents in rodents. Br J Nutr. 91: 533-538.

[141] Nagaoka S, Futamura Y, Miwa K, Awano T, Yamauchi K, Kanamaru Y, et al (2001) Identification of novel hypocholesterolemic peptides derived from bovine milk beta lactoglobulin. Biochem Biophys Res Commun. 281: 11-17.

[142] Shah, H. (2000) Effects of milk-derived bioactives: an overview. Br. J. Nutr. 84: 3-10.

[143] Siri-Tarino PW, Sun Q, Hu FB, Krauss RM (2010) Meta-analysis of prospective cohort studies evaluating the association of saturated fat with cardiovascular disease. Am J Clin Nutr. 91: 535-46

[144] Samuelson G, Bratteby LE, Mohsen R, Vessby B (2001) Dietary intake in healthy adolescents: inverse relationship between the estimated intake of saturated fatty acids and serum cholesterol. Br J Nutr. 85: 333-341.

[145] Jakobsen MU, O'Reilly EJ, Heitmann BL, Pereira MA, Bälter K, Fraser GE, et al (2009) Major types of dietary fat and risk of coronary heart disease: a pooled analysis of 11 cohort studies. Am J Clin Nutr. 89:1425-1432.

[146] Nestel PJ, Chronopulos A, Cehun M (2005) dairy fat in cheese raises LDL cholesterol less than that in butter in mildly hypercholesterolaemic subjects. Eur J Clin Nutr.59: 1059-1063.

[147] Biong AS, Müller H, Seljeflot I, Veierød MB, Pedersen JI, et al (2004) A comparison of the effects of cheese and butter on serum lipids, haemostatic variables and homocysteine. Br J Nutr. 92: 791-797

[148] Matthan NR, Welty FK, Barrett PH, Harausz C, Dolnikowski GG, Parks JS, et al (2004) Dietary hydrogenated fat increases high-density lipoprotein apoA-I catabolism and decreases low-density lipoprotein apoB-100 catabolism in hypercholesterolemic women. Arterioscler Thromb Vasc Biol. 24:1092-1097

[149] Pfeuffer M, Schrezenmeir J (2000) Bioactive substances in milk with properties decreasing risk of cardiovascular diseases. Br J Nutr. 84: 155-159

[150] Agerhol-Larsen L, Bell ML, Grunwald GK, Astrup A (2000) The effect of a probiotic milk product on plasma cholesterol: a metaanalysis of short-term intervention studies. Eur J Clin Nutr. 54: 856-860.

[151] Xiao JZ, Kondo S, Takahashi N, Miyaji K, Oshida K, Hiramatsu A, et al (2003) Effects of milk products fermented by Bifidobacterium longum on blood lipids in rats and healthy adult male volunteers. J Dairy Sci. 86: 2452- 2461

[152] Agerholm-Larsen L, Bell ML, Grunwald GK, Astrup A (2000) The effect of probiotic milk product on plasma cholesterol: a metaanalysis of short-term intervention studies. Eur. J. Clin. Nutr. 54: 856-860. 
[153] Expert Panel on Detection, Evaluation, and Treatment of High Blood Cholesterol in Adults. Executive Summary of the Third Report of the National Cholesterol Education Program (NCEP) Expert Panel on Detection, Evaluation, and Treatment of High Blood Cholesterol in Adults (Adult Treatment Panel III). JAMA. 2001;285:2486-2497

[154] Fraser GE (1999) Nut consumption, lipids, and risk of a coronary event. Clin Cardiol. 22:1-5.

[155] Kris-Etherton PM, Pearson TA, Wan Y, Hargrove RL, Moriarty K, Fishell V, et al (1999) High-monounsaturated fatty acid diets lower both plasma cholesterol and triglyceride concentrations. Am J Clin Nutr. 70:1009-1015

[156] Abbey M, Noakes M, Belling GB, Nestel PJ (1994) Partial replacement of saturated fatty acids with almonds or walnuts lowers total plasma cholesterol and low-densitylipoprotein cholesterol. Am J Clin Nutr.. 59: 995-999

[157] Morgan WA, Clayshulte BJ (2000) Pecans lower low-density lipoprotein cholesterol in people with normal lipid levels. J Am Diet Assoc. 100: 312-318.

[158] Zambón D, Sabaté J, Muñoz S, Campero B, Casals E, Merlos M, et al (2000) Substituting walnuts for monounsaturated fat improves the serum lipid profile of hypercholesterolemic men and women: a randomized crossover trial. Ann Intern Med. 132: 538-546

[159] Sabaté J, Fraser GE, Burke K, Knutsen SF, Bennett H, Lindsted KD (1993) Effects of walnuts on serum lipid levels and blood pressure in normal men. N Engl J Med. 328:603- 607.

[160] Edwards K, Kwaw I, Matud J, Kurtz I (1999) Effect of pistachio nuts on serum lipid levels in patients with moderate hypercholesterolemia. J Am Coll Nutr.18:229-232

[161] O'Byrne DJ, Knauft DA, Shireman RB (1997) Low fat-monounsaturated rich diets containing high-oleic peanuts improve serum lipoprotein profiles. Lipids. 32:687-695

[162] Schaefer EJ, Lichtenstein AH, Lamon-Fava S, Contois JH, Li Z, Rasmussen H, McNamara JR, et al (1995) Efficacy of a National Cholesterol Education Program Step 2 diet in normolipidemic and hypercholesterolemic middle-aged and elderly men and women. Arterioscler Thromb Vasc Biol. 15:1079-1085.

[163] Reaven P, Parthasarathy S, Grasse BJ, Miller E, Steinberg D, Witztum JL (1993) Effects of oleate-rich and linoleate-rich diets on the susceptibility of low density lipoprotein to oxidative modification in mildly hypercholesterolemic subjects. J Clin Invest. 91:668-676

[164] Spiller, G. A., Jenkins, D.A.J., Bosello, O., Gates, J. E., Cragen, L. N., Bruce B (1998) Nuts and plasma lipids: an almond-based diet lowers LDL-C while preserving HDL-C. J. Am. Coll. Nutr. 17: 285-290.

[165] Hyson DA, Schneeman BO, Davis PA (2002) Almonds and almond oil have similar effects on plasma lipids and LDL oxidation in healthy men and women. Almonds and almond oil have similar effects on plasma lipids and LDL oxidation in healthy men and women. J Nutr. 132: 703-707

[166] Garg ML, Blake RJ, Wills RB (2003) Macadamia nut consumption lowers plasma total and LDL cholesterol levels in hypercholesterolemic men. J Nutr. 133:1060-1063. 
[167] Li L, Tsao R, Yang R, Kramer JK, Hernandez M (2007) Fatty acid profiles, tocopherol contents, and antioxidant activities of heartnut (Juglans ailanthifolia var. cordiformis) and Persian walnut (Juglans regia L.). J Agric Food Chem. 55:1164-1169.

[168] Banel DK, Hu FB (2009) Effects of walnut consumption on blood lipids and other cardiovascular risk factors: a meta-analysis and systematic review. Am J Clin Nutr. 90: $56-63$

[169] Bazzano LA, Thompson AM, Tees MT, Nguyen CH, Winham DM (2011) Non-soy legume consumption lowers cholesterol levels: a meta-analysis of randomized controlled trials. Nutr Metab Cardiovasc Dis. 21: 94-103.

[170] Anderson JW, Major AW (2002) Pulses and lipaemia, short- and long term effect: potential in the prevention of cardiovascular disease. Br J Nutr. 88:263-271

[171] Duranti M (2006) Grain legume proteins and nutraceutical properties. Fitoterapia. 77: 67-82

[172] Mallillin AC, Trinidad TP, Raterta R, Dagbay K, Loyola AS (2008) Dietary fiber and fermentability characteristics of root crops and legumes. Br J Nutr. 100: 485-488.

[173] Roberfroid M (1997) Health benefits of non-digestible oligosaccharides. In Dietary Fiber in Health and Disease (Advances in Experimental Biology), p. 427 [D Kritchevsky and C Bonfield, editors]. New York: Plenum Press.

[174] Duane WC (1997) Effects of legume consumption on serum cholesterol, biliary lipids, and sterol metabolism in humans. J Lipid Res 38: 1120-1128

[175] Galisteo M, Duarte J, Zarzuelo A (2008) Effects of dietary fibers on disturbances clustered in the metabolic syndrome. J Nutr Biochem. 19: 71-84

[176] Rochfort S, Panozzo J (2007) Phytochemicals for health, the role of pulses. J Agric Food Chem. 55:7981-7994

[177] Denke M (1994) Role of beef tallow, an enriched source of stearic acid, in a cholesterol lowering diet. Am J Clin Nutr. 60: 1044S-1049S

[178] Scott LW, Dunn JK, Pownall HJ, Brauchi DJ, McMann MC, Herd JA, et al (1994) Effects of beef and chicken consumption on plasma lipid levels in hypercholesterolemic men. Arch Intern Med. 154: 1261-1267.

[179] Wolmarans P, Benadé AJS, Kotze TJvW, Daubitzer AK, Marais MP, Laubscher R (1991) Plasma lipoprotein response to substituting fish for red meat in the diet. Am J Clin Nutr. 53:1171-1176

[180] Davidson MH, Hunninghake D, Maki KC, Kwiterovich PO, Kafonek S (1999) Comparison of the effects of lean red meat vs lean white meat on serum lipid levels among free-living persons with hypercholesterolemia. Arch Intern Med. 159:1331-1338

[181] Lankinen M, Schwab U, Erkkilä A, Seppänen-Laakso T, Hannila ML, Mussalo H, et al (1991) Effects of a lean beef diet and of a chicken and fish diet on lipoprotein profiles. Nutr Metab Cardiovasc Dis. 1: 25-30.

[182] Morgan S, Sinclair A, O'Dea K (1993) Effect on serum lipids of addition of safflower oil or olive oil to very-low-fat diets rich in lean beef. J Am Diet Assoc. 93: 644- 648.

[183] Grundy SM. Cholesterol and atherosclerosis. Diagnosis and treatment. New York: Gower Medical Publishing, 1990 
[184] Lacaille B, Julien P, Deshaies Y, Lavigne C, Brun L-D, Jacques H (2000) Responses of plasma lipoproteins and sex hormones to the consumption of lean fish incorporated in a prudent-type diet in normolipidemic men. J Am Coll Nutr. 19: 745-753

[185] Gascon A, Jacques H, Moorjani S, Deshaies Y, Brun L-D, Julien P (1996) Plasma lipoprotein profile and lipolytic activities in response to the substitution of lean white fish for other animal protein sources in premenopausal women. Am J Clin Nutr. 63: 315-321

[186] Howell WH, McNamara DJ, Tosca MA, Smith BT, Gaines JA (1997) Plasma lipid and lipoprotein responses to dietary fat and cholesterol: a meta-analysis. Am J Clin Nutr.65:1747-1764.

[187] Dawber TR, Nickerson RJ, Brand FN, Pool J (1982) Eggs, serum cholesterol, and coronary heart disease. Am J Clin Nutr. 36:617-625

[188] Hu FB, Stampfer MJ, Rimm EB, Manson JE, Ascherio A, Colditz GA, et al (1999) A prospective study of egg consumption and risk of cardiovascular disease in men and women. JAMA. 281:1387-1394.

[189] Mayurasakorn K, Srisura W, Sitphahul P, Hongto PO (2008) High-density lipoprotein cholesterol changes after continuous egg consumption in healthy adults. J Med Assoc Thai. Mar. 91: 400-407.

[190] Mutungi G, Ratliff J, Puglisi M, Torres-Gonzalez M, Vaishnav U, Leite JO (2008) Dietary cholesterol from eggs increases plasma HDL cholesterol in overweight men consuming a carbohydrate-restricted diet. J Nutr. 138:272-176

[191] Fernandez ML (2006) Dietary cholesterol provided by eggs and plasma lipoproteins in healthy populations. Curr Opin Clin Nutr Metab Care. 9: 8-12.

[192] Harsha DW, Sacks FM, Obarzanek E, Svetkey LP, Lin PH, Bray GA (2004) Effect of dietary sodium intake on blood lipids: results from the DASH-sodium trial. Hypertension. 43: 393-398.

[193] Miller ER 3rd, Erlinger TP, Appel LJ (2006) The effects of macronutrients on blood pressure and lipids: an overview of the DASH and OmniHeart trials. Curr Atheroscler Rep. 8: 460-465.

[194] Obarzanek E, Sacks FM, Vollmer WM, Bray GA, Miller ER, Lin PH (2001) Effects on blood lipids of a blood pressure lowering diet: the Dietary Approaches to Stop Hypertension (DASH) Trial. Am J Clin Nutr. 74:80-89.

[195] Willett WC, Sacks F, Trichopoulou A, Drescher G, Ferro-Luzzi A, Helsing E, et al (1995) Mediterranean diet pyramid: a cultural model for healthy eating. Am J Clin Nutr. 6: $1402-1406$

[196] Tzima N, Pitsavos C, Panagiotakos DB, Skoumas J, Zampelas A, Chrysohoou C, et al (2007) Mediterranean diet and insulin sensitivity, lipid profile and blood pressure levels, in overweight and obese people; the Attica study. Lipids Health Dis. 6:22.

[197] Salen P, de Lorgeril M (1999) [Hyperlipidemias. Concern with the Mediterranean diet]. Presse Med.28:2018-2024.

[198] Demarin V, Lisak M, Morović S (2011) Mediterranean diet in healthy lifestyle and prevention of stroke. Acta Clin Croat. 50: 67-77.

[199] Willett WC. Public Health Nutr 2006;9:105 
[200] Mekki K, Bouzidi-bekada N, Kaddous A, Bouchenak M (2010) Mediterranean diet improves dyslipidemia and biomarkers in chronic renal failure patients. Food Funct.1: 10-5.

[201] Pitsavos, C., Panagiotakos, D.B., Tzima, N., Chrysohoou, C., Economou, M., Zampelas, A, et al (2005) Adherence to the Mediterranean diet is associated with total antioxidant capacity in healthy adults: the ATTICA study. Am. J. Clin. Nutr. 82: 694-699.

[202] Bouchard-Mercier A, Paradis AM, Godin G, Lamarche B, Pérusse L, Vohl MC (2010) Associations between dietary patterns and LDL peak particle diameter: a cross-sectional study. J Am Coll Nutr.29: 630-67.

[203] Ganguli D, Das N, Saha I, Biswas P, Datta S, Mukhopadhyay B (2011) Major dietary patterns and their associations with cardiovascular risk factors among women in West Bengal, India. Br J Nutr. 105:1520-1529

[204] Lim JH, Lee YS, Chang HC, Moon MK, Song Y (2011) Association between dietary patterns and blood lipid profiles in Korean adults with type 2 diabetes. J Korean Med Sci. 26: 1201-1208.

[205] Ambrosini GL, Huang RC, Mori TA, Hands BP, O'Sullivan TA, de Klerk NH, et al (2010) Dietary patterns and markers for the metabolic syndrome in Australian adolescents. Nutr Metab Cardiovasc Dis.20:274-283.

[206] FDA Talk Paper. FDA authorizes new coronary heart disease health claim for plant sterol and plant stanol esters. 5 September 2000. Washington (DC). Available from: http://www.fda.gov/Food/Labeling.Nutrition/LabelClaims/HealthClaimsMeetingSignifi cantScientificAgreementSSA/ucm074747.htm

[207] Manach C, Scalbert A, Morand C, Remesy C, Jimenez L (2004) Polyphenols: food sources and bioavailability. Am J Clin Nutr. 79:727-747

[208] Otaki N, Kimira M, Katsumata S, Uehara M, Watanabe S, Suzuki K (2009) Distribution and major sources of flavonoid intakes in the middle-aged Japanese women. J Clin Biochem Nutr. 44:231-238.

[209] Higgins JPT, Green S, eds. Highly sensitive search strategies for identifying reports of randomized controlled trials in MEDLINE. Cochrane handbook for systematic reviews of interventions 4.2.5 (updated May 2005); Appendix 5b. The Cochrane Library, Issue 3, 2005. Chichester, UK: Wiley \& Sons, Ltd. 2005.

[210] Frankel, E.N., Kanner, J., German, J.B., Parks, E., Kinsella, J.E (1993) Inhibition of oxidation of human low-density lipoprotein by phenolic substances in red wine. Lancet. 341:454-457.

[211] Otaki N, Kimira M, Katsumata S, Uehara M, Watanabe S, Suzuki K (2009) Distribution and major sources of flavonoid intakes in the middle-aged Japanese women. J Clin Biochem Nutr. 44: 231-8.

[212] Odbayar TO, Badamhand D, Kimura T, Takashi Y, Tsushida T, Ide T (2006) Comparative studies of some phenolic compounds quercetin, rutin, and ferulic acid) affecting hepatic fatty acid synthesis in mice. J Agric Food Chem. 54:8261-8265

[213] Princen HM, van Duyvenvoorde W, Buytenhek R, Blonk C, Tijburg LB, Langius JA, et al (1998) No effect of consumption of green and black tea on plasma lipid and 
antioxidant levels and on LDL oxidation in smokers. Arterioscler Thromb Vasc Biol. 18:833-841

[214] Bingham, S. A., Vorster, H., Jerling, J. C., Magee, E., Mulligan, A., Runswick, S. A., Cummings, J. H. (1997) Effect of black tea drinking on blood lipids, blood pressure and aspects of bowel habit. Brit. J. Nutr. 78: 41-55

[215] van het Hof KH, de Boer HS, Wiseman SA, Lien N, Westrate JA, Tijburg LB (1997) Consumption of green or black tea does not increase resistance of low-density lipoprotein to oxidation in humans. Am J Clin Nutr. 66:1125-1132

[216] McAnlis GT, McEneny J, Pearce J, Young IS (1998) Black tea consumption does not protect low density lipoprotein from oxidative modification. Eur J Clin Nutr. 52:202-206

[217] Duffy SJ, Vita JA, Holbrook M, Swerdloff PL, Keaney JF (2001) Effect of acute and chronic tea consumption on platelet aggregation in patients with coronary artery disease. Arterioscler Thromb Vasc Biol. 21: 1084-1089

[218] Maron DJ, Lu GP, Cai NS, Wu ZG, Li YH, Chen H, Zhu JQ, et al (2003) Cholesterollowering effect of a theaflavin-enriched green tea extract: a randomized controlled trial. Arch Intern Med. 163:1448-1453.

[219] Tokunaga S, White IR, Frost C, Tanaka K, Kono S, Tokudome S (2002) Green tea consumption and serum lipids and lipoproteins in a population of healthy workers in Japan. Ann Epidemiol.12: 157-165.

[220] Kris-Etherton PM, Keen CL (2002) Evidence that the antioxidant flavonoids in tea and cocoa are beneficial for cardiovascular health. Curr Opin Lipidol. 13:41-49.

[221] Ikeda I, Imasato Y, Sasaki E, Nakayama M, Nagao H, Takeo T, et al (1992) Tea catechins decrease micellar solubility and intestinal absorption of cholesterol in rats. Biochim Biophys Acta. 1127:141- 146.

[222] Yang TT, Koo MW (2000) Chinese green tea lowers cholesterol level through an increase in fecal lipid excretion. Life Sci. 66:411-423

[223] Chan PT, Fong WP, Cheung YL, Huang Y, Ho WK, Chen ZY (1999) Jasmine green tea epicatechins are hypolipidemic in hamsters (Mesocricetus auratus) fed a high fat diet. J Nutr. 129:1094-1101.

[224] Bursill C, Roach PD, Bottema CD, Pal S (2001) Green tea upregulates the low-density lipoprotein receptor through the sterol-regulated element binding protein in HepG2 liver cells. J Agric Food Chem. 49: 5639-5645

[225] Matsumoto N, Okushio K, Hara Y (1998) Effect of black tea polyphenols on plasma lipids in cholesterol-fed rats. J Nutr Sci Vitaminol. 44:337-342

[226] Crews WD Jr, Harrison DW, Wright JW (2008) A double-blind, placebocontrolled, randomized trial of the effects of dark chocolate and cocoa on variables associated with neuropsychological functioning and cardiovascular health: Clinical findings from a sample of healthy, cognitively intact older adults. Am J Clin Nutr. 87:872-880.

[227] Farouque HM, Leung M, Hope SA, Baldi M, Schechter C, Cameron JD, Meredith IT (2006) Acute and chronic effects of flavanol-rich cocoa on vascular function in subjects with coronary artery disease: a randomized double-blind placebo-controlled study. Clin Sci. 111: 71-80. 
[228] Lecumberri E, Goya L, Mateos R, Alía M, Ramos S, Izquierdo-Pulido M, et al (2007) A diet rich in dietary fiber from cocoa improves lipid profile and reduces malondialdehyde in hypercholesterolemic rats. Nutrition. 23:332-41.

[229] Rein D, Lotito S, Holt RR, Keen CL, Schmitz HH, Fraga CG (2000) Epicatechin in human plasma. In vivo determination and effect of chocolate consumption on plasma oxidation status. J Nutr. 130: 2109-2114.

[230] Mathur S, Devaraj S, Grundy SM, Jialal I (2002) Cocoa products decrease low density lipoprotein oxidative susceptibility but do not affect biomarkers of inflammation in humans. J Nutr. 132:3663-3667.

[231] Jia L, Liu X, Bai YY, Li SH, Sun K, He C, et al (2010) Short-term effect of cocoa product consumption on lipid profile: a meta-analysis of randomized controlled trials. Am J Clin Nutr. 92:218-225.

[232] Keen CL, Holt RR, Oteiza PI, Fraga CG, Schmitz HH (2005) Cocoa antioxidants and cardiovascular health. Am J Clin Nutr. 81:298-303.

[233] Schmidt M, Schmitz HJ, Baumgart A, Guédon D, Netsch MI, Kreuter MH, Schmidlin CB, et al (2005) Toxicity of green tea extracts and their constituents in rat hepatocytes in primary culture. Food Chem Toxicol. 43: 307-14.

[234] Vinson JA, Proch J, Bose P, Muchler S, Taffera P, Shuta D, et al (2006) Chocolate is a powerful ex vivo and in vivo antioxidant, an antiatherosclerotic agent in an animal model, and a significant contributor to antioxidants in the European and American Diets. J Agric Food Chem. 54:8071-6.

[235] Basch E, Ulbricht C, Kuo G, Szapary P, Smith M (2003) Therapeutic applications of fenugreek. Altern Med Rev. 8:20-27.

[236] Handa T, Yamaguchi K, Sono Y, Yazawa K (2005) Effects of fenugreek seed extract in obese mice fed a high-fat diet. Biosci Biotechnol Biochem. 69: 1186-1188.

[237] Gupta R, Nair S (1999) Antioxidant flavonoids in common Indian diet. South Asian J Prev Cardio. 3:83-94.

[238] Petit PR, Sauvaire YD, Hillaire-Buys DM, Leconte OM, Baissac YG, Ponsin GR (1995) Steroid saponins from fenugreek seeds: extraction, purification, and pharmacological investigation on feeding behavior and plasma cholesterol. Steroids. 60:674-80

[239] Broca C, Breil V, Cruciani-Guglielmacci C, Manteghetti M, Rouault C, Derouet M, et al (2004) Insulinotropic agent ID-1101 (4-hydroxyisoleucine) activates insulin signaling in rat. Am J Physiol Endocrinol Metab. 287:463-71

[240] Dixit PP, Misar A, Mujumdar AM, Ghaskadbi S (2010) Pre-treatment of Syndrex protects mice from becoming diabetic after streptozotocin injection. Fitoterapia. 81(5):403-12

[241] Udayasekhara Rao P, Sesikeran B, Srinivasa Rao P, Nadamnui A, Vikas Rao V, Ramachandra RP (1996) Short term Nutritional and safety evaluation of Fenugreek. Nutr Res 16(9): 1495-1505

[242] Praveen KB, Dasgupta DJ, Prashar BS, Kaushal SS (1987) Preliminary Report: Effective reduction of LDL cholesterol by indigenous plant products. Current Science. 56(12): 8081

[243] Saibaba A, Raghuram TC (1997) Fenugreek - The wonder Seed. Nutrition 31(2): 21-25. 
[244] Neeraja A, Rajyalakshmi P (1996) Hypoglycemic effect of processed fenugreek seeds in humans. J Food Sci Technol. 33: 427-430.

[245] Muwalla MM, Abuirmmeileh NM (1991) Suppression of avian hepatic cholesterogenesis by dietary ginseng. J Nutr Biochem. 1:518- 521

[246] Zheng X, Yan Y (1991) The effect of ginsenosides of ginseng stem and leaf (GSL) on the lipid regulation and lipid peroxidation in chronic hyperlipidemic rabbits. Zhongguo Yaolixue Tonbao. 7:110-116

[247] Kim SH, Park KS (2003) Effects of Panax ginseng extract on lipid metabolism in humans. Pharmacol Res. 48:511-513.

[248] Kim SH, Park KS (2003) Effects of Panax ginseng extract on lipid metabolism in humans. Pharmacol Res. 48:511-513.

[249] Yamamoto M, Kumagai A (1984) Long term ginseng effects on hyperlipidemia in man with further study of its actions on atherogenesis and fatty liver rats. In: Proceedings of the 4th International Ginseng Symposium at Korea Ginseng \& Tobaco Research Institute. p. 13-20.

[250] Joo CN. The preventive effect of Korean ginseng saponins on aortic atheroma formation in prolonged cholesterol fed rabbits. In: Proceedings of the 3rd International Ginseng Symposium at Korea Ginseng \& Tobaco Research Institute; 1980. p. 27-36

[251] Kang DG, Yun YG, Ryoo JH, Lee HS (2002) Anti-hypertensive effect of water extract of danshen on renovascular hypertension through inhibition of the renin angiotensin system. Am J Chin Med. 30:87-93

[252] Yokozawa T, Kobayashi T, Kawai A, Oura H, Kawashima Y (1985) Hyperlipidemiaimproving effects of ginseoside-Rb2in cholesterolfed rats. Chem Pharm Bull. 33:722729.

[253] Langner E, Greifenberg S, Gruenwald J (1998) Ginger: history and use. Adv Ther 15:25-44

[254] Gruenwald J, Brendler T, Jaenicke C (2000) PDR for herbal medicines, 2nd edn. Medical Economics Company, Inc, Montvale, NJ

[255] Bhandari U, Kanojiah R, Pillai KK (2005) Effect of ethanol extract of Zingiber officinale on dyslipidaemia in diabetic rats. J Ethnopharmacol 97: 227-230

[256] Mary JM, John PK (2000) Agents used in hyperlipidaemia. In: Katzung BG (ed) Basic and clinical pharmacology, 8th edn. McGraw Hill Comp, New York, pp 581-595

[257] Afshari AT, Shirpoor A, Farshid A, Saadatian R, Rasmi Y, Saboory E et al (2007) The effect of ginger on diabetic nephropathy, plasma antioxidant capacity and lipid peroxidation in rats. Food Chem 101:148-153

[258] Belinky PA, Aviram M, Fuhrman B, Rosenblat M, Vaya J (1998) The antioxidative effects of the isoflavan glabridin on endogenous constituents of LDL during its oxidation. Atherosclerosis. 137:49-61

[259] Demizu S, Kajiyama K, Takahashi K, Hiraga Y, Yamamoto S, Tamura Y, et al (1988) Antioxidant and antimicrobial constituents of licorice: isolation and structure elucidation of a new benzofuran derivative. Chem Pharm Bull (Tokyo). 36: 3474-3479. 
[260] Belinky PA, Aviram M, Fuhrman B, Rosenblat M, Vaya J (1998) The antioxidative effects of the isoflavan glabridin on endogenous constituents of LDL during its oxidation. Atherosclerosis. 137: 49

[261] Fuhrman B, Volkova N, Kaplan M, Presser D, Attias J, Hayek T, et al (2002) Antiatherosclerotic effects of licorice extract supplementation on hypercholesterolemic patients: increased resistance of LDL to atherogenic modifications, reduced plasma lipid levels, and decreased systolic blood pressure. Nutrition. 18: 268-273. 